\title{
An observationally constrained estimate of global dust aerosol optical depth
}

\author{
David A. Ridley ${ }^{1}$, Colette L. Heald ${ }^{1}$, Jasper F. Kok ${ }^{2}$, and Chun Zhao ${ }^{3}$ \\ ${ }^{1}$ Civil and Environmental Engineering, Massachusetts Institute of Technology, Cambridge, MA, USA \\ ${ }^{2}$ Department of Atmospheric and Oceanic Sciences, UCLA, Los Angeles, CA, USA \\ ${ }^{3}$ Atmospheric Sciences and Global Change Division, Pacific Northwest National Lab, Richland, WA 99352, USA
}

Correspondence to: David A. Ridley (daridley@mit.edu)

Received: 8 May 2016 - Published in Atmos. Chem. Phys. Discuss.: 20 May 2016

Revised: 27 October 2016 - Accepted: 18 November 2016 - Published: 6 December 2016

\begin{abstract}
The role of mineral dust in climate and ecosystems has been largely quantified using global climate and chemistry model simulations of dust emission, transport, and deposition. However, differences between these model simulations are substantial, with estimates of global dust aerosol optical depth (AOD) that vary by over a factor of 5 . Here we develop an observationally based estimate of the global dust AOD, using multiple satellite platforms, in situ AOD observations and four state-of-the-science global models over 2004-2008. We estimate that the global dust AOD at $550 \mathrm{~nm}$ is $0.030 \pm 0.005(1 \sigma)$, higher than the AeroCom model median (0.023) and substantially narrowing the uncertainty. The methodology used provides regional, seasonal dust AOD and the associated statistical uncertainty for key dust regions around the globe with which model dust schemes can be evaluated. Exploring the regional and seasonal differences in dust AOD between our observationally based estimate and the four models in this study, we find that emissions in Africa are often overrepresented at the expense of Asian and Middle Eastern emissions and that dust removal appears to be too rapid in most models.
\end{abstract}

\section{Introduction}

Mineral dust is a key component of aerosol, affecting climate through interaction with radiation, clouds and snowpack, human health through contribution to particulate matter (PM), and ecosystem health through nutrient transport and deposition. The direct radiative effect (DRE) of dust contributes $\sim 30 \%$ of the total aerosol global mean DRE (Heald et al.,
2014); however, there is significant uncertainty in the radiative forcing of dust, estimated to be anywhere between -0.3 and $+0.1 \mathrm{Wm}^{-2}$ (Boucher et al., 2013), owing to large uncertainties in the anthropogenically driven changes in dust (Ginoux et al., 2012; Heald and Spracklen, 2015), the particle morphology and absorption properties (e.g., Balkanski et al., 2007; Mishra et al., 2008), and the dust size distribution (Kok, 2011; Kok et al., 2016). Dust concentrations are often highest in remote regions that are sparsely monitored, leading to further uncertainty on the atmospheric burden and the associated radiative effects.

Dust aerosol can be transported far downwind of desert source regions, having a significant impact on the surface PM thousands of kilometers downwind (Prospero, 2007; Prospero et al., 2014; Zhang et al., 2013). This poses a significant health concern through cases of premature mortality from respiratory and cardiovascular disease that are attributed to aerosol exposure (Lim et al., 2012). Studies attempting to quantify the global premature mortality from aerosol exposure (e.g., van Donkelaar et al., 2006; Evans et al., 2013) highlight the strong contribution of dust to PM across large regions of Africa, Asia, and the Middle East. Because of the lack of surface monitoring in dust-influenced regions, those studies rely on satellite observations of aerosol optical depth (AOD), a measure of the column-integrated aerosol that is critical for understanding the radiative effect. Relating the AOD to surface PM requires information on the vertical distribution and aerosol speciation, generally obtained from models, which can introduce considerable uncertainty (Ford and Heald, 2016). Limited observations of global dust 
aerosol hinder our ability to estimate the full extent of the climate and air quality impacts of mineral dust.

To simulate the global dust cycle, models must be able to predict the vertical dust flux from suitable regions and represent the evolution of the particle size distribution while the dust is transported and deposited out of the atmosphere (e.g., Kok et al., 2012). The AeroCom project, an intercomparison and evaluation of different aerosol models, provides a detailed evaluation of dust aerosol simulations from multiple models (Huneeus et al., 2011). There is a considerable spread in global dust AOD estimates from models ranging from 0.010 to 0.053 (yielding a mean of $0.028 \pm 0.011$ ) and an AeroCom "median model" estimate of 0.023 . The uncertainty in the AOD highlights the underlying uncertainties in emissions, size distributions, lifetime, and optical properties. Even over the well-studied, most productive dust region of West Africa, climate models struggle to represent dust emission and their year-to-year changes (Evan et al., 2014).

An observationally constrained estimate of dust AOD can thus provide a valuable metric to holistically evaluate model dust emission, transport, and deposition, thereby helping constrain both the DRE and the role of dust in adverse health effects from exposure to PM. Here we derive such a metric, with consideration for the sources of uncertainty, and use it to highlight seasons and regions in which current global models deviate from the observations.

\section{Data description}

To derive an estimate of dust AOD we make use of AOD retrievals from three satellite instruments as well as surfacebased sun photometers to provide a "ground truth" for correcting the satellite retrievals. We use four global aerosol models to provide a range of estimates for the non-dust aerosol AOD and the spatial distribution of dust aerosol (see Sect. 3 for a full description of the methodology). We use observational data and model simulations over the 5-year period between 2004 and 2008, except when calculating biases between satellite and surface-based observations, for which we leverage a longer dataset between 2003 and 2013. Below we give a brief description of each instrument and model and the products used.

\subsection{Moderate Resolution Imaging Spectroradiometer (MODIS)}

Two MODIS instruments are in sun-synchronous orbit aboard the Terra and Aqua platforms, making equatorial overpasses at 10.30 and 14.30 local time (LT), respectively. Radiance measurements are made across 36 bands between 0.4 and 14 microns, with seven channels used to retrieve the AOD at $550 \mathrm{~nm}$. The wide swath $(2330 \mathrm{~km})$ allows almost daily coverage of the globe by both instruments at a native resolution of $500 \mathrm{~m}$ at nadir ( $2 \mathrm{~km}$ at swath edge), for the aerosol-relevant bands, with AOD reported at approximately $10 \mathrm{~km} \times 10 \mathrm{~km}$ resolution (Level 2 product). The Collection 6 MODIS data include a merged AOD product that combines retrievals over ocean, vegetated land surface (Dark Target), and bright land surface (Deep Blue) to maximize global coverage. The retrieved AOD $(\tau)$ is estimated to be accurate to $\pm 0.03 \pm 0.05 \tau$ over ocean (Remer et al., 2005), $\pm 0.05 \pm 0.15 \tau$ over dark land surfaces (Levy et al., 2010), and $\pm 0.05 \pm 0.20 \tau$ over bright surfaces (Hsu et al., 2006; Sayer et al., 2013). The quality-assured (QA) Level 2 AOD retrievals are aggregated daily onto a $1^{\circ} \times 1^{\circ}$ grid (Level 3) with statistics, including cloud fraction and standard deviation. Throughout this study we use the Level 3 product. The merged Level 3 product uses $\mathrm{QA}=3$ data over land and $\mathrm{QA}=1-3$ data over ocean, where higher quality data are given commensurate weighting. Baddock et al. (2016) show that correlation between the frequency of high AOD and dust source location is actually improved when using only $\mathrm{QA}=1$ data. For data to be considered QA $>1$ the standard deviation in AOD between $1 \mathrm{~km}$ retrievals must remain below a threshold of 0.18 . Therefore, some legitimate dustinfluenced retrievals over source may be discarded when using the Level 3 merged product. However, this is a trade off in terms of improving the quality of the retrieval away from source regions. The MODIS retrieval algorithm uses a lookup table of surface reflectance for a set of simulated aerosol properties to determine the AOD that best represents the observed reflectance. For the Deep Blue retrieval, the most relevant to this study over dust-influenced regions, the assumed optical properties of the dust aerosol have a singlescattering albedo (SSA) between 0.87 and 1.0 for the lookup tables at 412 and $490 \mathrm{~nm}$ and a refractive index of 1.55 $0.0 i($ at $670 \mathrm{~nm})$. The Mie calculation uses an effective phase function, derived from comparison of the Sea-Viewing Wide Field-of-View Sensor (SeaWIFS) instrument retrievals with AERONET, over the ocean to account for nonsphericity. Different locations and loading conditions trigger changes in the wavelengths used in the retrieval, more information can be found in Hsu et al. $(2004,2013)$

\subsection{Multi-angle Imaging SpectroRadiometer (MISR)}

The MISR instrument, aboard the Terra satellite platform, measures radiance over nine camera angles with an equatorial overpass at $10.30 \mathrm{LT}$. The relatively narrow swath width $(400 \mathrm{~km})$ results in global coverage every 9 days, compared with 1-2 days by MODIS. MISR provides AOD at four wavelengths $(446,558,672,867 \mathrm{~nm})$ with about threequarters of retrievals falling within $0.20 \tau$ (but no less than 0.05 ) of AERONET observations (we assume an instrument uncertainty of $\pm 0.05 \pm 0.20 \tau$ throughout this study) and reliable retrieval over bright desert surfaces (Kahn et al., 2010; Martonchik et al., 1998, 2004). In this study, we use the Level 3 daily $0.5^{\circ} \times 0.5^{\circ}$ resolution gridded AOD product. The MISR retrieval algorithm uses simulated top-of-atmosphere 
radiances using properties for eight particle types to determine the AOD. The optical properties of the two aerosol particle types corresponding to dust assume a refractive index of 1.51-6.5 $\times 10^{-4} i$ and SSA between 0.971 and 0.994 (at $672 \mathrm{~nm}$ ). The extinction is calculated using the discrete dipole approximation and the $T$ matrix technique to account for particle nonsphericity (Kalashnikova et al., 2005; Martonchik et al., 2009).

\subsection{Aerosol Robotic Network (AERONET)}

AERONET consists of a global network of Cimel Electronique CE-318 sun photometers, which reports AOD with a high degree of accuracy leading to estimated errors of 0.01-0.02 (Eck et al., 1999; Holben et al., 1998). Direct sun measurements are made every $15 \mathrm{~min}$ at 340, 380, 440, 500, 675, 870, 940, and $1020 \mathrm{~nm}$ and AOD is retrieved at all but the $940 \mathrm{~nm}$ channel, which is used to provide total column water vapor. We use Level 2.0 data that have been screened for clouds (Smirnov et al., 2000). The wavelength dependence of the AOD, described by the Ångström exponent (Ångström, 1964) between the AOD at 440 and at $870 \mathrm{~nm}$, is used to distinguish AOD dominated by coarse aerosol that is indicated by a lower Ångström exponent than for fine aerosol (e.g., O'Neill et al., 2001; Reid et al., 1999). Sun photometer measurements made from aboard ship cruises as part of the AERONET Maritime Aerosol Network (MAN; Smirnov et al., 2011) are incorporated into the AERONET analysis in this work.

\subsection{GEOS-Chem}

We use the GEOS-Chem global chemical transport model (v9-01-03; http://www.geos-chem.org) to simulate the coupled oxidant-aerosol chemistry of the troposphere at a resolution of $2.5^{\circ}$ by $2.0^{\circ}$ over 47 vertical levels following the specifications used in (Heald et al., 2014). The oxidant-aerosol simulation includes $\mathrm{H}_{2} \mathrm{SO}_{4}-\mathrm{HNO}_{3}-\mathrm{NH}_{3}$ aerosol thermodynamics described by ISORROPIA II (Fountoukis and Nenes, 2007) and coupled with an $\mathrm{O}_{3}-\mathrm{NO}_{x}-$ hydrocarbon chemical mechanism (Park et al., 2004, 2006). The aerosol simulation also includes carbonaceous aerosols (Park et al., 2003; Pye et al., 2010; Pye and Seinfeld, 2010), mineral dust (Fairlie et al., 2007; Ridley et al., 2012), and sea salt (Alexander et al., 2005). Aerosol mass is transported in four size bins $(0.1-1.0,1.0-1.8,1.8-3.0$, and 3.0$6.0 \mu \mathrm{m}$ radius) for dust, two for sea salt, and one for each of the other species. The model is driven by assimilated meteorology from the NASA Modern-Era Retrospective analysis for Research and Applications (MERRA), which provides winds, precipitation, etc., could cover at 1-hourly and 3-hourly temporal resolution. Dust emissions are generated using the DEAD scheme (Zender, 2003) with the GOCART source function (Ginoux et al., 2001; Prospero et al., 2002) and a fixed soil clay fraction of 0.2. We fol- low Ridley et al. (2013) by using a probability distribution of subgrid scale winds, generated from $0.5^{\circ} \times 0.67^{\circ}$ MERRA $10 \mathrm{~m}$ winds, rather than the average wind speed when calculating dust uplift. Biomass burning emissions are provided by the Global Fire Emissions Database version 3 (GFEDv3; van der Werf et al., 2010). Anthropogenic emissions are provided by the Emissions Database for Global Atmospheric Research (EDGAR) v3.2 inventory (Olivier, 2001) for $\mathrm{SO}_{x}, \mathrm{NO}_{x}$, and $\mathrm{CO}$, which is superseded by the National Emissions Inventory (NEI99; http://www.epa.gov/ $\mathrm{ttn} /$ chief/net/1999inventory.html) over the United States and Streets et al. (2003, 2006) over Asia (van Donkelaar et al., 2008). Sea salt emissions follow Gong (2003) with added dependence on sea surface temperature (Jaeglé et al., 2011). $\mathrm{AOD}$ at $550 \mathrm{~nm}$ is calculated online assuming lognormal size distributions of externally mixed aerosols and is a function of the local relative humidity to account for hygroscopic growth (Martin et al., 2003). Aerosol optical properties are based on the Global Aerosol Data Set (GADS) (Hess et al., 1998a) with modifications to the size distribution based on field observations (Drury et al., 2010; Jaeglé et al., 2011) and improvements to the UV-visible refractive indices of dust (Sinyuk et al., 2003).

\subsection{Community Earth System Model (CESM)}

The CESM, version 1.1 (Hurrell, 2013), is used in this study following the specifications described in Kok et al. (2014b). The atmospheric component of the model, the Community Atmospheric Model version 4 (CAM4), is run at $2.5^{\circ} \times 1.9^{\circ}$ resolution and is driven by ERA-Interim reanalysis meteorology (Dee et al., 2011) with free-running dynamics. CAM4 simulates aerosol as bulk species from the Model for OZone And Related chemical Tracers (MOZART) chemistry package (Lamarque et al., 2012), including sulfate, ammonium, ammonium nitrate, black carbon, organic carbon, and secondary organic aerosol. Emissions of these species are prescribed by the AeroCom specifications (Neale et al., 2010). Sea salt is emitted and transported in four size bins and is calculated from $10 \mathrm{~m}$ wind speed (Mahowald et al., 2006). Dust emission in the Community Land Module version 4 (CLM4) is traditionally based on the DEAD dust scheme (Zender, 2003) with some minor modifications (Mahowald et al., 2006, 2010). Here we use the new dust emission model developed in Kok et al. (2014a), which generates a vertical dust flux with no prescribed source function and accounts for the exponential increase in dust flux with increasing soil erodibility. This dust emission model better reproduces both small-scale dust emission measurements (Kok et al., 2014a) and its implementation in CESM results in improved agreement against AERONET measurements in dusty regions (Kok et al., 2014b). Dust is emitted into four size bins $(0.1-1.0,1.0-2.5,2.5-5.0$, and $5.0-10 \mu \mathrm{m}$ diameter $)$, and the fraction emitted into each bin is independent of wind speed, as shown by measurements (Kok, 2011b), and dis- 
tributed following brittle fragmentation theory (Kok, 2011a). All aerosols are assumed externally mixed. The aerosol optical properties are based on GADS (Hess et al., 1998a) with improvements to the dust optical properties described in Albani et al. (2014). Prescribed size distributions that can be found in Emmons et al. (2010).

\subsection{WRF-Chem}

The quasi-global configuration of the WRF-Chem (version 3.5.1) model is used in this study, described in detail in $\mathrm{Hu}$ et al. (2016). The simulation uses the MOSAIC (Model for Simulation Aerosol Interactions and Chemistry) aerosol module (Zaveri et al., 2008) with the CBM-Z (carbon bond mechanism) photochemical mechanism (Zaveri and Peters, 1999). A sectional approach is used to represent aerosol size distributions with eight discrete size bins and all major aerosol components including sulfate $\left(\mathrm{SO}_{4}^{-2}\right)$, nitrate $\left(\mathrm{NO}_{3}^{-}\right)$, ammonium $\left(\mathrm{NH}_{4}^{+}\right)$, black carbon, organic matter, sea salt, methanesulfonic acid, and mineral dust are simulated. The MOSAIC aerosol scheme includes physical and chemical processes of nucleation, condensation, coagulation, aqueous phase chemistry, and water uptake by aerosols. The model is run at a resolution of $1^{\circ} \times 1^{\circ}$ (between $180^{\circ} \mathrm{W}-180^{\circ} \mathrm{E}$ and $67.5^{\circ} \mathrm{S}-77.5^{\circ} \mathrm{N}$ ) with 35 vertical layers up to $50 \mathrm{hPa}$ (Hu et al., 2016). The modeled $u$ and $v$ wind components and temperature in the free atmosphere above the planetary boundary layer are nudged towards NCEP/FNL reanalyses on 6-hourly time steps (Stauffer and Seaman, 1990). Biomass burning emissions are derived from GFEDv3. Anthropogenic emissions are provided by the REanalysis of the TROpospheric (RETRO) chemical composition inventories (http: //gcmd.gsfc.nasa.gov/) except over East Asia, where emissions are taken from the inventory developed for the INTEXB mission in 2006 (Zhang et al., 2009), updated with $\mathrm{SO}_{2}$ and carbonaceous emissions from Lu et al. (2011), and the United States, where the National Emissions Inventory (NEI) for 2005 is used. Sea salt emissions are based on Gong (2003), with added emission dependence on sea surface temperature (Jaeglé et al., 2011). Dust emission fluxes are calculated with the GOCART dust emissions scheme (Ginoux et al., 2001) and partitioned into the MOSAIC size bins based on brittle fragment theory (Kok, 2011a). Aerosol optical properties are computed as a function of wavelength for each model grid box. Aerosols are assumed internally mixed (a volumetric mean refractive index) in each bin. The Optical Properties of Aerosols and Clouds (OPAC) dataset (Hess et al., 1998b) is used for the shortwave and longwave refractive indices of aerosols, except that a constant value of $1.53+0.003 i$ is used for the shortwave refractive index of dust following Zhao et al. $(2010,2011)$. A detailed description of the aerosol optical properties calculated in WRF-Chem can be found in Fast et al. (2006) and Barnard et al. (2010). The optical properties and direct radiative forcing of individual aerosol species in the atmosphere are diagnosed following the methodology described in Zhao et al. (2013).

\subsection{MERRAero}

The NASA Global Modeling and Assimilation Office (GMAO) GEOS-5 Earth system model can be run in a configuration that assimilates meteorological and aerosol properties retrieved from NASA Earth observing satellite platforms (Rienecker et al., 2011). The resulting aerosol simulation is termed MERRAero. The simulation is run at a resolution of $0.5^{\circ} \times 0.625^{\circ}$ providing speciated AOD with 3-hourly temporal resolution. The aerosol processes are based on the Goddard Chemistry, Aerosol, Radiation and Transport model (GOCART; Chin et al., 2002) with coupling of chemistry and climate (Colarco et al., 2010). Dust, sulfate, organic carbon, black carbon, and sea salt are simulated as external mixtures. Dust aerosol is partitioned into eight size bins between 0.1 and $10 \mu \mathrm{m}$ particle radius, and sea salt aerosol is partitioned into five size bins between 0.03 and $10 \mu \mathrm{m}$ dry radius; all other aerosol is transported in a single size bin per species. Emissions of fossil fuels and biofuel follow the GOCART model (Chin et al., 2002) with updates in the US following Park et al. (2003). $\mathrm{SO}_{2}$ emissions are from the EDGAR4.1 inventory with altered injection profiles (Buchard et al., 2014) and biomass burning emissions are supplied from the NASA Quick Fire Emission Dataset (QFED) version 2.1. Sea salt aerosol production follows Gong (2003) with added dependence on sea surface temperature (Jaeglé et al., 2011). The aerosol optical properties follow GADS, but with modifications to reduce the absorption of dust at short wavelengths (Sinyuk et al., 2003), and extinction is calculated following Mie theory assuming spherical particles (Colarco et al., 2010). MERRAero differs from the other three models used in that the model assimilates AOD information from the MODIS instruments. The assimilation process is explained in detail in Buchard et al. (2016); here we give a brief description. The MODIS reflectances are cloud screened and converted to AOD using a neural net framework. The error covariance between the 2-D MODIS AOD and the model AOD is used to generate 3-D aerosol mass increments. Using a local displacement ensemble methodology, ensembles of isotropic displacements in aerosol mass around a central grid box are weighted based upon the reduction in the error. Different aerosol species can be perturbed in each vertical layer, e.g., to allow a plume to be shifted to better match the MODIS AOD, and therefore aerosol mass can vary independently for each species.

\section{Methodology}

\subsection{Derivation of dust AOD}

Our aim is to provide seasonal dust AOD estimates, both global and regional, that are as independent from modeled 


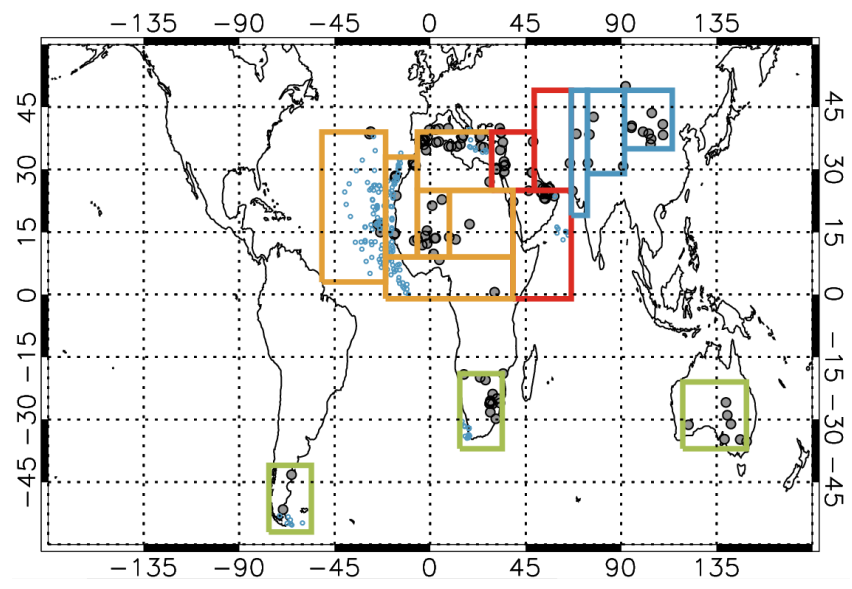

Figure 1. The 15 regions considered explicitly in this study are defined. Regions are grouped into African (orange), Middle Eastern (red), Asian (blue), and southern hemispheric (green). AERONET sites (gray circles) and Maritime Aerosol Network observations (blue dots) used to bias correct satellite AOD are indicated. The regions are identified as (1) mid-Atlantic, (2) northern Africa, (3) Gulf of Guinea, (4) west coast, (5) Mali/Niger, (6) Bodele Depression and Sudan region, (7) northern Middle East, (8) southern Middle East, (9) Kyzyl Kum, (10) Thar, (11) Taklamakan, (12) Gobi, (13) South America, (14) South Africa, and (15) Australia.

dust estimates as possible. The methodology and development of associated uncertainty estimates are described in detail below, but the general methodology is as follows: we rely primarily on satellite retrievals of AOD, which we biascorrect using dust-dominated AERONET AOD retrievals. To partition the retrieved AOD in dusty regions between the component due to dust and the component due to other aerosols, we use simulated estimates of non-dust AOD with several global models in 15 regions that are identified as contributing significantly to the global dust AOD. These regions are defined such that they account for most dust AOD, based on model estimates, and are shown in Fig. 1. Finally, model dust AOD is used to estimate the fraction of dust AOD that is outside of the 15 dust-dominated regions, thereby providing global seasonal dust AOD estimates between 2004 and 2008. Our methodology accounts for many uncertainties, including the satellite retrieval error, estimation of seasonal mean AOD, bias correction, modeled non-dust AOD, and global scaling factors. We discuss potential biases that are not accounted for in Sect. 4.4.

We aggregate daily AOD data from MISR and both MODIS instruments (Aqua and Terra) onto a $2^{\circ} \times 2.5^{\circ}$ grid and average over 3-month periods to increase coverage and provide a consistent grid between model and observations. We use bootstrapping (Efron and Gong, 1983) to estimate the random uncertainty in the seasonally averaged AOD due to sampling uncertainty within each grid box. This is achieved by randomly sampling (with replacement) the grid box daily AOD $n$ times, where $n$ is the number of days with a retrieval in that 3-month period, and the mean of the samples calculated. This is repeated to build a probability distribution of the seasonal AOD for each grid box. We find that a lognormal distribution is a good approximation to the resulting seasonal AOD uncertainty distribution, so we retain the mean and standard deviation of this distribution as the mean and uncertainty on the seasonal $\log _{10}$ (AOD) for each grid box.

Although the bootstrapping method quantifies the random error in each grid box's seasonal AOD, it does not quantify or correct the systematic error (bias) in the AOD. Therefore, we use AERONET AOD as ground truth to apply a bias correction to the satellite-retrieved $\mathrm{AOD}$, with a focus on dustinfluenced regions. AERONET hourly AOD (interpolated to $550 \mathrm{~nm})$ is used to produce a morning (10.00-12:00 LT) and afternoon (13.00-15.00 LT) average to compare with daily retrievals from aboard the Terra and Aqua satellites, respectively. We compare these at the native satellite retrieval resolution and choose a 2-hour window to both cover the approximate range of the overpass times and to maximize the number of coincident AERONET and satellite AOD retrievals. We use all AERONET sites within the regions defined in Fig. 1 and aggregate all data in each region for the comparison. For the regions encompassing ocean we also use AOD measurements from the AERONET MAN where available (see Fig. 1). We generate histograms of the daily $\log _{10}$ (AOD) from AERONET and each satellite instrument using data between 2003 and 2013 (see Figs. S1-S3 in the Supplement) and present the statistics of the bias and linear regression for each region in Table 1. Although 2004-2008 is the main period of study in this research we use 11 years of AERONET and satellite retrievals to maximize the amount of data and better characterize the biases. More than 100 days of colocated data available are required for the bias correction to be applied to a region - a criterion usually met, except for MISR in some Asian deserts. The standard deviation of the bias correction is derived from each pair of daily $\log _{10}(\mathrm{AOD})$ in a region and is used to propagate this uncertainty into the global dust AOD estimate (see below). If not enough data are available, we apply a bias correction of 1.0 (i.e., no bias) with a standard deviation of $\pm 50 \%$ to represent the uncertainty.

On average across all sites, both MODIS instruments show a slight high mean annual bias in AOD relative to AERONET retrievals $(+10 \%$ for Terra, $+4 \%$ for Aqua; see Table 2$)$, although there is considerable variability between regions and on a day-to-day basis (indicated by the correlation coefficient, $r$, in Table 1). MISR is also biased high relative to AERONET $(+16 \%)$, due primarily to retrievals when $\mathrm{AOD}<0.5$, but also exhibits a low bias for AOD $>1.0$, consistent with previous comparisons, e.g., Moon et al. (2015). Splitting the data by season does not yield qualitatively different results; however, it reduces the number of data points in some regions enough to make comparison unreliable. Therefore, we apply an annual bias correction per region. The bias correction has a moderate impact on the average global dust AOD, decreasing it by $10 \%$ and bringing the 

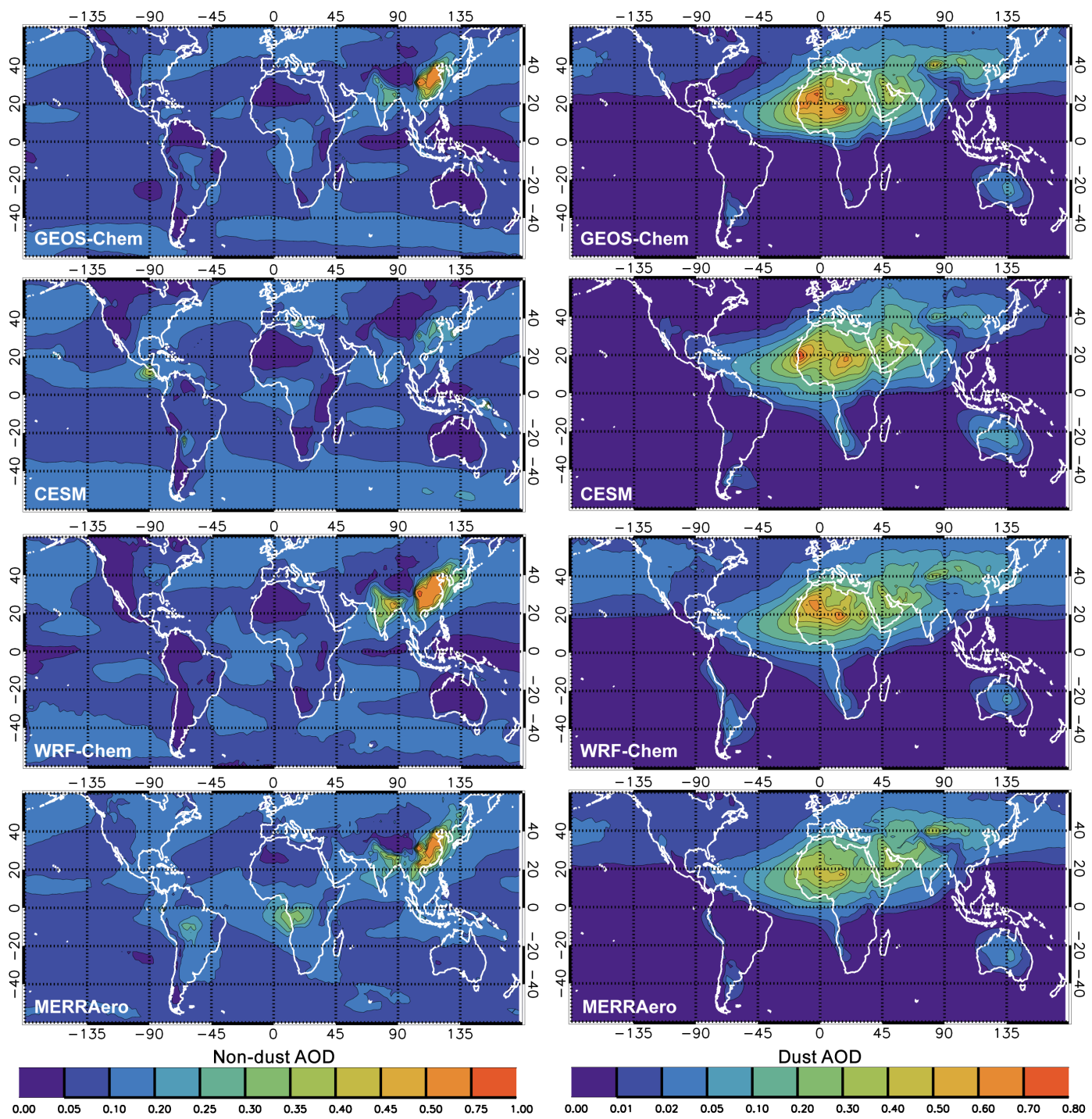

Figure 2. Annual non-dust AOD (left) and dust AOD (right) at $550 \mathrm{~nm}$ for the four models used in this study. Data are averaged over 2004-2008.

individual satellite instruments into closer agreement. However, the large uncertainty on the bias correction (see Table 1) is a major source of the uncertainty on the global dust AOD (see Table 2).

Although dust aerosol is often the main contributor to the AOD in the regions shown in Fig. 1, other aerosol species can make a significant contribution and need to be accounted for to extract dust AOD from the satellite retrievals of AOD. We use GEOS-Chem, CESM, WRF-Chem, and MERRAero to provide non-dust AOD; using multiple models provides an estimate of the variability in the non-dust portion of the AOD resulting from uncertainty in aerosol emissions and formation mechanisms. Anthropogenic aerosol is generally well characterized by global models, especially on seasonal timescales, and has been regularly evaluated against observations, particularly in the Northern Hemisphere (e.g., Hu et al., 2016; Leibensperger et al., 2012; Liu et al., 2012; Mann et al., 2014). We focus on regions in which the dust AOD often dominates to reduce potential errors from biases in modeled non-dust AOD. Biomass burning aerosol concentrations are inherently uncertain because of the challenges in determining burned area and emissions factors (French et al., 2004; van der Werf et al., 2006). Despite considerable evaluation against observations the resulting biomass burning AOD is sometimes underrepresented (Matichuk et al., 2007; Reddington et al., 2016); therefore, we treat regions affected by biomass burning emissions with caution. In the regions analyzed, dust aerosol plays a key role and often dominates in the spring and summer, limiting the influence of the model non-dust AOD. Exceptions to this are in South America, South Africa, and Australia, which have a minimal impact on the global dust AOD, and the Gulf of Guinea, where 
Table 1. Bias corrections applied to satellite AOD retrievals in each of the regions (see Fig. 1) based on comparison with AERONET daily AOD between 2003 and 2013 (see Figs. S1-S3).

\begin{tabular}{|c|c|c|c|c|c|c|}
\hline \multirow[t]{3}{*}{ Region } & \multicolumn{6}{|c|}{ AERONET bias correction and correlation coefficient } \\
\hline & \multicolumn{2}{|c|}{ MODIS (Aqua) } & \multicolumn{2}{|c|}{ MODIS (Terra) } & \multicolumn{2}{|l|}{ MISR } \\
\hline & NMB & $r$ & NMB & $r$ & NMB & $r$ \\
\hline Mid-Atlantic & $0.82 \pm 0.07$ & 0.93 & $0.86 \pm 0.06$ & 0.93 & $0.84 \pm 0.04$ & 0.93 \\
\hline North Africa & $0.91 \pm 0.22$ & 0.79 & $1.01 \pm 0.12$ & 0.80 & $0.99 \pm 0.09$ & 0.83 \\
\hline Gulf of Guinea & $0.90 \pm 0.10$ & 0.84 & $1.01 \pm 0.11$ & 0.83 & $0.92 \pm 0.10$ & 0.82 \\
\hline West coast & $1.04 \pm 0.17$ & 0.80 & $1.04 \pm 0.19$ & 0.83 & $0.94 \pm 0.10$ & 0.87 \\
\hline Mali/Niger & $0.98 \pm 0.17$ & 0.86 & $0.95 \pm 0.17$ & 0.87 & $0.93 \pm 0.12$ & 0.83 \\
\hline Bodele/Sudan & $1.01 \pm 0.19$ & 0.68 & $0.99 \pm 0.19$ & 0.76 & $0.91 \pm 0.07$ & 0.70 \\
\hline Northern Middle East & $0.81 \pm 0.10$ & 0.75 & $0.86 \pm 0.12$ & 0.73 & $0.95 \pm 0.08$ & 0.77 \\
\hline Southern Middle East & $1.01 \pm 0.11$ & 0.77 & $1.06 \pm 0.11$ & 0.78 & $0.88 \pm 0.06$ & 0.84 \\
\hline Kyzyl Kum & $1.02 \pm 0.29$ & 0.83 & $1.05 \pm 0.22$ & 0.82 & $1.19 \pm 0.10$ & 0.80 \\
\hline Thar & $1.03 \pm 0.12$ & 0.84 & $1.04 \pm 0.15$ & 0.84 & $1.28 \pm 0.14$ & 0.79 \\
\hline Taklamakan & $0.82 \pm 0.17$ & 0.66 & $0.98 \pm 0.21$ & 0.79 & $0.77 \pm 0.16$ & 0.47 \\
\hline Gobi & $0.98 \pm 0.41$ & 0.54 & $0.90 \pm 0.42$ & 0.45 & $0.66 \pm 0.28$ & 0.73 \\
\hline South America & $0.85 \pm 0.15$ & 0.43 & $0.95 \pm 0.22$ & 0.18 & $0.56 \pm 0.15$ & 0.27 \\
\hline South Africa & $1.44 \pm 0.23$ & 0.73 & $1.71 \pm 0.27$ & 0.74 & $1.08 \pm 0.11$ & 0.89 \\
\hline Australia & $1.02 \pm 0.32$ & 0.42 & $1.01 \pm 0.28$ & 0.43 & $0.92 \pm 0.10$ & 0.82 \\
\hline
\end{tabular}

significant biomass burning aerosol is present (we consider results with and without these regions, see Table 1). In addition, most regions considered in this study are inland and therefore sea salt aerosol will have a limited impact. Figure 2 displays the climatology of non-dust AOD and dust AOD for each model used, averaged over 2004-2008.

For each $2^{\circ} \times 2.5^{\circ}$ grid box, $i$, within the 15 regions we apply the AERONET-derived bias correction, $\alpha$, to the seasonal satellite AOD, $\tau^{\text {obs }}$, and subtract the model non-dust AOD, $\tau_{\mathrm{nd}}^{\text {model }}$, to provide an estimate of the regional dust AOD, $\tau_{\mathrm{d}}^{\text {reg }}$ (Eq. 1). We allow negative values of $\tau_{\mathrm{d}}^{\text {reg }}$ so as not to introduce a positive bias. The uncertainty distribution for each of these three variables - bias correction, satellite $\log _{10}$ (AOD), and model non-dust $\log _{10}$ (AOD) - is sampled and the average dust AOD is calculated for each region. This process is repeated multiple times to yield a stable distribution of seasonal dust AOD (200 times is sufficient for a robust average) for each of the regions between 2004 and 2008. For a single iteration of the dust AOD calculation we use the same random sampling (sampling the same number of sigma from the mean) for all grid boxes, thereby assuming the worst-case scenario that the uncertainty is correlated spatially. If we use a different sampling of the uncertainty distribution for each grid box, the uncertainty on the global dust AOD drops by approximately a factor of 8 .

$\tau_{\mathrm{d}}^{\mathrm{reg}}=\frac{1}{N} \sum_{i}^{N} \alpha_{i} \tau_{i}^{\mathrm{obs}}-\tau_{\mathrm{nd}, i}^{\text {model }}$

The regional dust AOD, $\tau_{\mathrm{d}}^{\text {reg }}$, for the 15 regions is weighted by surface area, $A^{\text {reg }}$, summed, and scaled by the surface area of the Earth, $A_{\mathrm{E}}$, to give the total regional contribution to the global dust AOD (Eq. 2). To obtain the globally averaged dust AOD, $\tau_{\mathrm{d}}^{\text {glob }}$, we calculate the ratio, $\beta$, between the modeled dust AOD across all regions and the modeled global dust AOD (Eq. 3).

$$
\begin{aligned}
& \tau_{\mathrm{d}}^{\text {glob }}=\beta \frac{1}{A_{\mathrm{E}}} \sum_{r}^{N^{\text {reg }}} A^{\text {reg }} \tau_{\mathrm{d}}^{\text {reg }} \\
& \beta=\frac{\tau_{\mathrm{d}}^{\text {glob,model }}}{\frac{1}{A_{\mathrm{E}}} \sum_{r}^{N^{\text {reg }}} A^{\text {reg }} \tau_{\mathrm{d}}^{\text {reg,model }}}
\end{aligned}
$$

This allows the satellite estimate within the regions to be scaled to a global dust AOD estimate. This is the only element of our analysis that relies upon simulated dust AOD. The 15 regions account for between 83 and $95 \%$ of the global dust AOD, depending on the model, so the model influence is limited and using multiple models provides an estimate of the uncertainty this introduces into our analysis (see Table 1). This process is repeated for all combinations of the three satellite instruments, four model estimates for non-dust, and four model regional-to-global scaling factors; this produces 48 realizations, 16 per satellite instrument, each with an uncertainty estimate. We use the kernel density estimation method (Silverman, 1986) with a Gaussian kernel and standard smoothing to determine a probability density function for the global dust AOD based on the 48 realizations. 
Table 2. Each source of uncertainty is assessed in terms of the impact upon the global dust AOD mean and standard deviation. The sign of the relative uncertainty indicates whether the uncertainty yields a bias about the average or is assumed symmetrical. For the model non-dust AOD and regional-to-global scaling the bias is defined as the difference between the upper and lower estimate of the global dust AOD when the source of uncertainty is isolated. Italicized uncertainties are explored but not incorporated into the global dust AOD uncertainty estimate. Values here are for correlated errors between neighboring $2 \times 2.5^{\circ}$ grid cells; assuming errors within a region are uncorrelated (i.e., a different number of sigma from the mean for each grid cell in an iteration) yields $\sim 8 \times$ smaller uncertainty.

\begin{tabular}{lrr}
\hline Source of uncertainty & $\begin{array}{r}\text { Relative bias in } \\
\text { global dust AOD }\end{array}$ & $\begin{array}{r}\text { Relative contribution } \\
\text { to uncertainty }\end{array}$ \\
\hline Instrument retrieval uncertainty & $<1 \%$ & $+5 \%$ \\
Satellite retrieval of seasonal AOD & $<1 \%$ & $+13 \%$ \\
Model non-dust AOD & $\pm 8 \% \mathrm{a}$ & $+6 \%$ \\
Model regional-to-global scaling & $\pm 6 \%$ & $+4 \%$ \\
AERONET bias correction & $-10 \%$ & $+56 \%$ \\
(MODIS Aqua, MODIS Terra, MISR) & $(-4,-10,-16 \%)$ & $(+64,+73,+50 \%)$ \\
Satellite retrieval spatial sampling & $<1 \%$ & - \\
(MODIS Aqua, MODIS Terra, MISR) & $(<1,<1,+1.3 \%)$ & $(+7,+7,+50 \%)$ \\
Satellite retrieval diurnal sampling & $-4 \%$ & $+2 \%$ \\
(MODIS Aqua, MODIS Terra, MISR) & $(-5,-1,-2 \%)$ & $(-1,+2,+3 \%)$ \\
Cloud filtering (> 80 \%) & $-13 \%$ & $<1 \%$ \\
Inclusion of S.H. desert regions & $2 \%$ & $+6 \%$ \\
Inclusion of Gulf of Guinea & $+6 \%$ b & $+9 \%$ \\
\hline a May not be symmetrical about the mean (see Supplement, Fig. S4). ${ }^{\mathrm{b}}$ Relative to global dust AOD without \\
AERONET bias correction.
\end{tabular}

\section{Results}

\subsection{The observationally constrained global dust AOD}

Figure. 3 shows the global dust AOD estimates with the associated probability density function generated using the kernel density estimation method for each satellite and for the entire ensemble. The global dust AOD for the four models used in this study is also displayed, along with the AeroCom models in Huneeus et al. (2011) with the associated probability density function generated using the kernel density estimation method. Our observational estimate of the global dust AOD is $0.030 \pm 0.005(1 \sigma)$ and is thus much more narrowly constrained than the AeroCom estimate of $0.028 \pm 0.011$. Over three-quarters $(77 \%)$ of the ensemble members fall above the AeroCom model mean global dust AOD; however, the broadness of the AeroCom model distribution implies that a global dust AOD greater than 0.035 would be required for statistically significant disagreement at the $95 \%$ confidence level (i.e., $p<0.05$; in this case $p=0.63$ ). Relative to the dust AOD from the four models used in this study (see Fig. 2), all lie within $1 \sigma$ of the observational estimate. The average global dust AOD estimates from each satellite instrument are remarkably similar (MODIS Aqua: $0.030 \pm 0.004$; MODIS Terra: $0.030 \pm 0.004$; MISR: $0.030 \pm 0.006$ ). This is partially owing to the AERONET bias correction that decreases the AOD from all satellite instruments and brings them into closer agreement. The AERONET bias correction suggests that the satellite AOD is generally biased high in dusty regions, based on the available data for comparison in the regions of interest (see Figs. S1 to S3). On an annual basis, the observationally constrained global dust AOD varies between 0.028 and 0.032 , with good agreement in the interannual variability in dust AOD derived from the three instruments (Fig. 4). The dust AOD is similar for years between 2004 and 2006 before increasing in 2007 and peaking in 2008, largely driven by a sharp increase across the Middle East (Yu et al., 2015). The AeroCom model simulations are representative of the year 2000; therefore, some of the difference between the global dust AOD in this study and that from the AeroCom study may derive from the interannual variability. However, the annual global dust AOD for each year equals or exceeds the AeroCom mean and median. Figures 3 and 4 suggest that the global dust AOD from models in this study is in general agreement with the observational AOD constraints; whereas the models from the AeroCom study show more diversity. We note that the global dust AOD masks important regional differences that are discussed in Sect. 4.3. Furthermore, considerable uncertainty remains on the dust loading despite the similarities in global dust AOD as a result of compensating differences in dust emission, optics, and aerosol size distribution assumptions (e.g., Albani et al., 2014; Balkanski et al., 2007; Cakmur et al., 2006). A follow-on study indicates that both the abundance and extinction efficiency of dust are underestimated in models and better constrains these factors to improve estimates of the dust impact on global climate (Kok et al., 2016). 


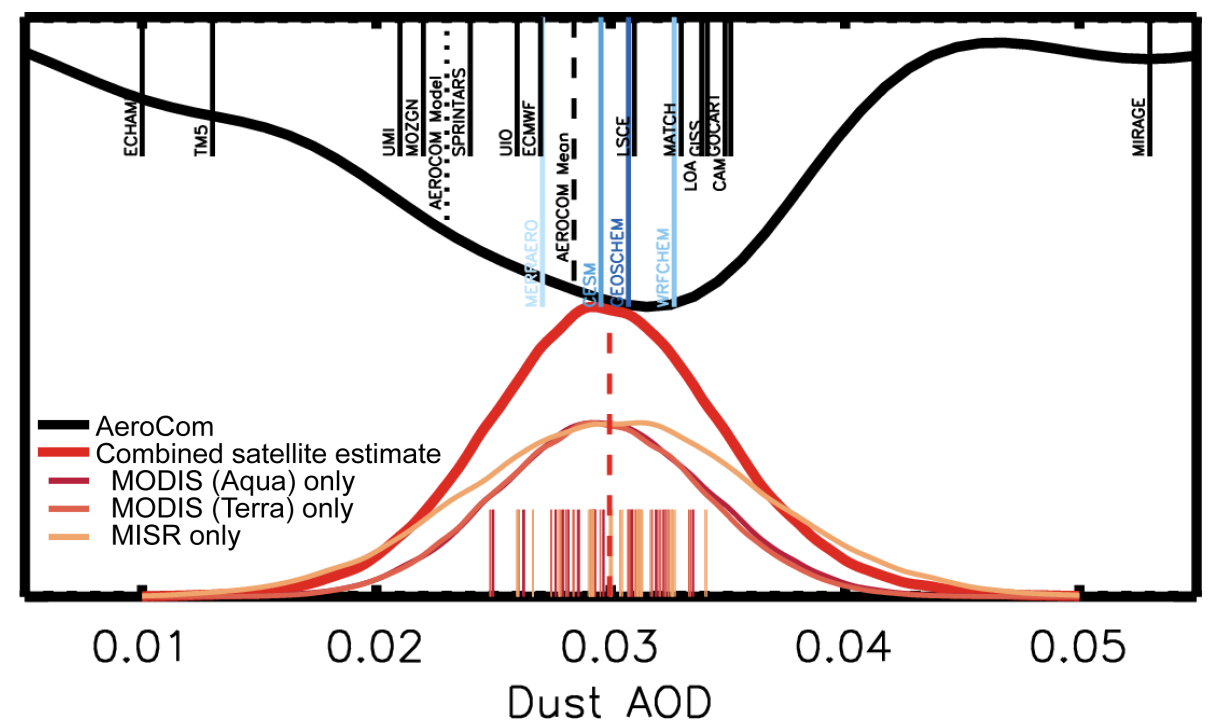

Figure 3. The global dust AOD adapted from Huneeus et al. (2011) for 14 AeroCom models (vertical black lines) and the associated probability density function (PDF) (solid black line), mean (dashed black line), and the AeroCom median model (dotted black line) are shown along with the global dust AOD from the four models used in this study (vertical blue lines). The PDF of the observationally constrained dust AOD estimate of this study (red) with the associated mean (dashed red line) is shown on the bottom axis. The PDF of the observationally constrained dust AOD derived from each of the satellite instruments is shown (red hues) with the individual ensemble members (vertical red hue lines).

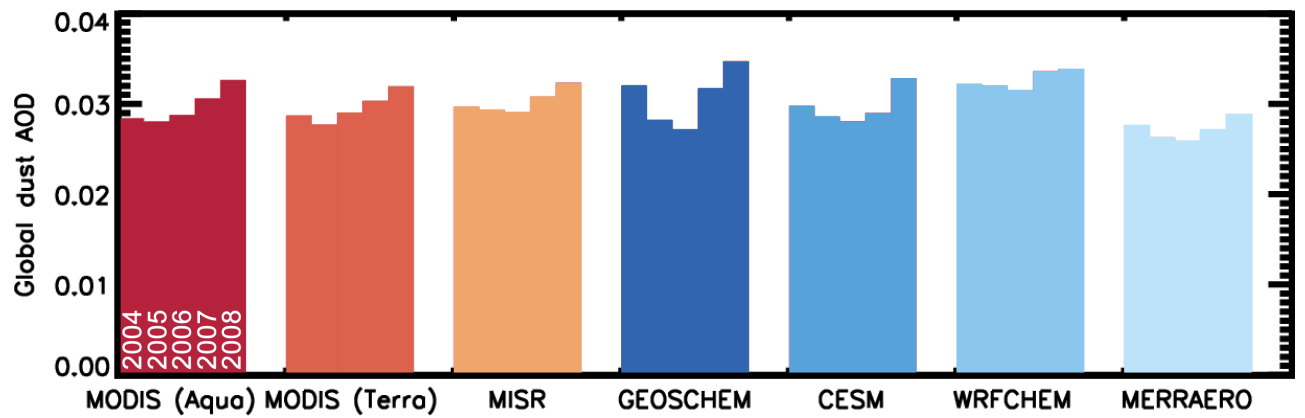

Figure 4. Annual global dust AOD for 2004-2008 derived from the three satellite instruments (red hues) and from the four models (blue hues). The annual dust AOD from the satellite instruments is an average of the ensemble members for that instrument.

\subsection{Uncertainties in the observational estimate of global dust AOD}

Table 1 summarizes the uncertainties considered in this study, in terms of both potential bias to the global dust AOD and the contribution to the standard deviation of the estimate (0.005). The latter is quantified by assessing the reduction in the spread of the global dust AOD probability density function (PDF) when the uncertainty for a factor is omitted. The leading uncertainty arises from the AERONET bias correction ( $\alpha$, Eq. 1). The bias correction yields a decrease in the global dust AOD of $10 \%$ and brings the estimates from each satellite instrument into close agreement, but the uncertainty on the bias correction accounts for over half of the ultimate uncertainty on the global dust AOD. The instrument retrieval errors contribute $5 \%$ of the uncertainty, whereas es- timating the seasonal satellite AOD from a limited number of retrievals contributes $13 \%$ of the total uncertainty. The difference in regional-to-global dust AOD scaling from models and the difference in non-dust AOD from models yield \pm 6 and $\pm 8 \%$ uncertainty, respectively, on the estimated global dust AOD. The latter uncertainty is primarily a consequence of higher non-dust AOD in MERRAero than the other three models and therefore a lower estimate of dust AOD. The uncertainty from non-dust AOD may not be symmetrical about the mean and is discussed further in Sect. 4.4 and in Supplement. The regional-to-global scaling factor ( $\beta$, Eq. 3$)$ is strongly dependent upon the dust lifetime within the model and ranges from 1.20 to 1.45 , a lower scaling factor indicative of less dust far from source and therefore a shorter dust lifetime. The uncertainty from the regional-to-global scaling 

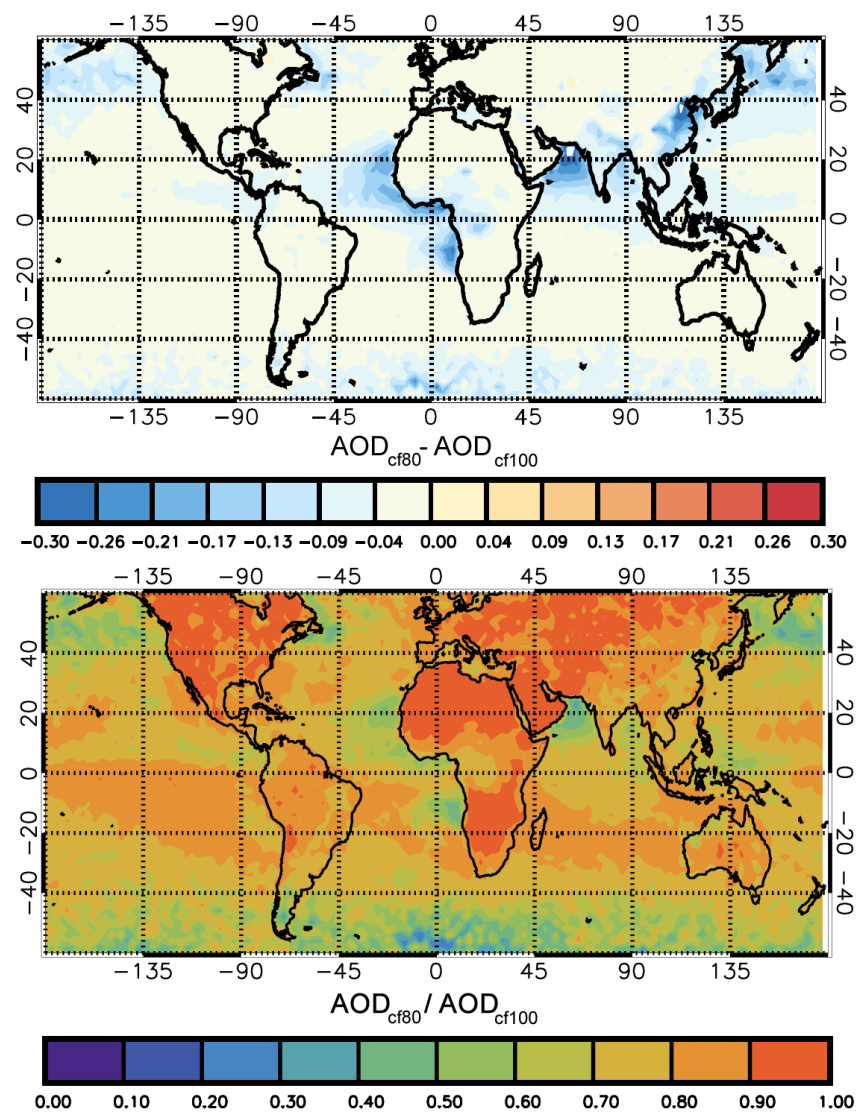

Figure 5. The absolute change (top) and fractional change (bottom) in the annual MODIS Aqua AOD (averaged over 2004-2008) when applying a filter to remove any Level 3 data that contain more than $80 \%$ cloudy Level 2 pixels.

may not be symmetrical about the mean if the model dust lifetime estimates are biased low, as analysis of dust outflow into the mid-Atlantic suggests (see later discussion).

Other factors that are explored, but not encompassed by the uncertainty estimate on the global dust AOD, are the impact of spatial and temporal sampling biases in the satellite data (e.g., overpass timing and frequency, regions of persistent cloud, high latitudes), cloud filtering of satellite AOD retrievals, and inclusion of the Gulf of Guinea region. These are also included in Table 1 and discussed below.

Satellite retrieval of AOD is only possible in clear sky conditions and at locations that fall within the satellite swath; therefore, the observed dust AOD will not take into account the effect of dust present before or after the satellite overpass and in the presence of clouds. We assess the impact of this sampling bias by processing the AOD from the four models in the same way as the satellite-retrieved AOD, including masking the daily AOD data where no satellite retrieval is available. By comparing the modeled dust AOD with and without masking, we determine that the impact of satellite sampling upon the global dust AOD estimate is minimal: $<1 \%$ for the MODIS instruments and $+1.3 \%$ for MISR.
Masking does, however, increase the uncertainty in the dust AOD estimate by $7 \%$ when sampling is based on MODIS and $50 \%$ when sampling to the sparser MISR retrievals. Because the masking effectively removes cloudy regions, the very small change in the modeled global dust AOD suggests that there is no obvious bias in the global dust AOD when including regions within cloudy air masses, relative to clearsky only. To explore the clear-sky and all-sky differences further, we calculated GEOS-Chem global dust AOD after masking columns that have $>50 \%$ cloud cover in any grid box, based on MERRA reanalysis. This causes the global dust AOD to increase by $2 \%$, relative to when no masking is used, indicating that the difference between clear-sky and all-sky dust AOD is small. However, we acknowledge that poor representation of clouds in the reanalysis meteorology or potential satellite misclassification of heavy dust loading as cloud (Darmenov and Sokolik, 2009) could lead to a stronger perceived relationship between dust loading in cloudy and clear sky conditions.

The sun-synchronous orbit of the Terra and Aqua satellites results in overpass at similar morning and afternoon local time, respectively, each day. Therefore, a significant daily cycle in the AOD would create a bias in the inferred daily AOD. For all dust-influenced AERONET sites, we compare the 10:00-12:00 and 14:00-16:00 LT AOD to the daily AOD (calculated from all available retrievals within the daytime) between 2002 and 2012. We find that, on the days with $\mathrm{AE}>0.4$ at the AERONET sites used in this study, the AOD during the morning and the afternoon is closely related to the daily AOD, deviating by $<2 \%$ on average. This is in agreement with Smirnov et al. (2002), who found that AOD varied diurnally by less than $10 \%$ at dust-influenced AERONET sites. When the satellite-retrieved AOD is bias corrected to the daily AOD, rather than the AOD at time of overpass (as done here), we find that the dust AOD is $4 \%$ lower (see Table 1).

By filtering MODIS daily AOD $1^{\circ} \times 1^{\circ}$ retrievals that contain more than $80 \%$ cloudy Level 2 pixels we find that the AOD drops considerably in the mid-Atlantic, Gulf of Guinea, and the Arabian Sea (Fig. 5). This leads to significantly different estimates for the dust AOD in certain regions (Fig. 6). The largest impact is seen in the mid-Atlantic where the dust AOD declines by $40 \%$ on average when filtering for clouds. The models also decrease when the equivalent masking is applied, but only by $20 \%$ on average in this region. This suggests that the filtering preferentially removes higher dust AOD cases, but the association of high dust AOD with cloudy regions is stronger in the observations than in the model. Similarly, reductions in dust AOD of up to $30 \%$ in winter and spring are produced by cloud filtering in the Gulf of Guinea. In the southern part of the Arabian Peninsula and the Arabian Sea the summertime peak in dust AOD is decreased by $30 \%$ by filtering pixels with more than $80 \%$ cloud cover. Cloud filtering of Level 2 retrievals is generally considered conservative in Collection 6 and misclassification is more common 

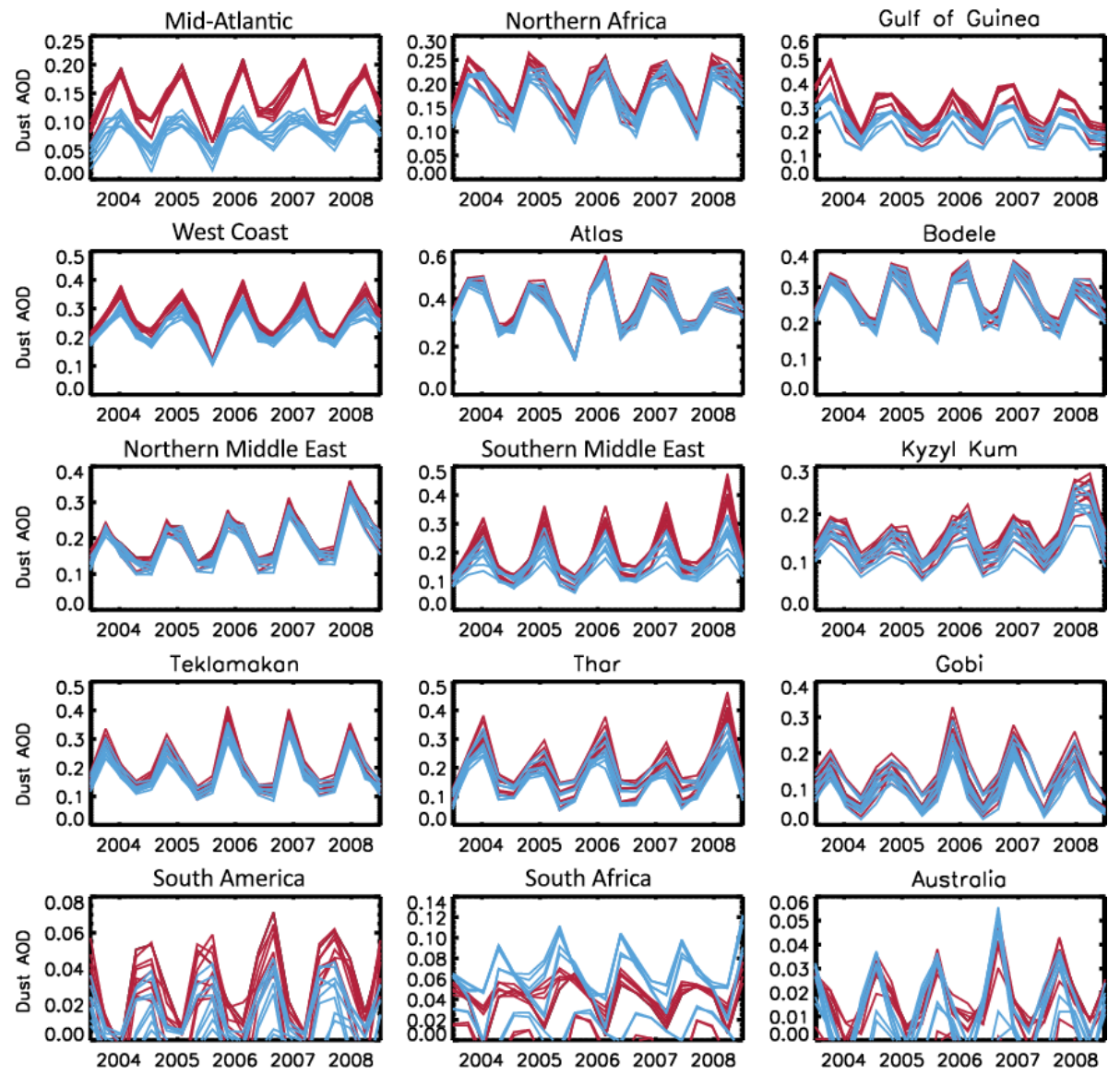

Figure 6. Observational dust AOD from MODIS Aqua and Terra with (red) and without (blue) filtering of $1^{\circ} \times 1^{\circ}$ daily regions with over $80 \%$ cloud cover. Each line corresponds to a different combination of satellite and model when calculating the dust AOD, indicating the uncertainty. Results are shown without any bias correction from AERONET.

for thin cirrus than for cumulus cloud decks (Levy et al., 2013; Remer et al., 2012). Therefore, removal of large regions in which high dust loading is associated with cumulus and stratus clouds may introduce an erroneous negative bias. It is also possible that high AOD retrieval in cloudy regions is the result of hygroscopicity and 3-D cloud effects (Koren et al., 2007; Marshak et al., 2008; Quaas et al., 2010). Indeed, it has been shown in studies using AERONET that AOD can increase dramatically between clouds and may be mistakenly screened as cloud (Eck et al., 2014). While this is a legitimate AOD enhancement, we cannot expect the global models with $>100 \mathrm{~km}$ resolution using assimilated meteorology to reproduce enhancements from near-cloud hygroscopic growth or 3-D cloud effects on scattering. The observational-estimate of dust AOD provided in our analysis does not include the extra cloud filtering; we rely on the screening provided as part of the MODIS retrieval, rather than arbitrarily filtering the cloud-cleared product. However, the AERONET and MAN bias correction does decrease the AOD substantially, especially in the mid-Atlantic (up to a $20 \%$ decrease), and so may partially account for the higher AOD associated with cloudy regions.

The regions defined around the South American, southern African, and Australian deserts and the outflow cover relatively large areas that are only intermittently affected by dust (see Fig. 1). This may increase the likelihood of misattribution of non-dust AOD as dust AOD. We find that including those regions in the analysis does not have a significant impact on the global dust AOD, increasing it by $2 \%$, although it causes a $6 \%$ increase in the uncertainty. In contrast, including the Gulf of Guinea region increases the dust AOD by $+6 \%$ and increases the uncertainty by $9 \%$. The dust AOD in the Gulf of Guinea region is consistently higher in the observational estimate than the models owing to a combination of persistent cloud cover, high biomass burning emissions in winter that are not always captured by the models, and a lack of dust towards the Equator in the models that may result from too efficient convective wet removal. To prevent an artificially high bias in the global dust AOD, we do not explicitly evaluate the Gulf of Guinea region in our estimates beyond the assessment of uncertainty in Table 1. This region 
is still accounted for in the global dust AOD via the regionalto-global dust AOD scaling (the 14 remaining regions account for $77-87 \%$ of the global dust AOD, depending on the model).

\subsection{Comparison of modeled and observed regional dust AOD}

Model dust emissions are often tuned to a specific annual global emission mass (Fairlie et al., 2007; Huneeus et al., 2011) or scaled to a global AOD inferred from assimilations (Mahowald et al., 2006; Rasch et al., 2001). The annual global dust AOD derived from the models in this study shows encouragingly similar interannual variability to the observationally constrained estimates (see Fig. 4). However, tuning the models globally will not necessarily produce the right spatial and seasonal distribution. Here we use the observational constraints developed in this study to highlight regional and seasonal discrepancies between models and observations to isolate potential errors that affect multiple models. We compare the interannual variability globally and the seasonal dust AOD aggregated over broad regions for each of the models with the observational estimates from each satellite instrument (Fig. 7a). We also compare the climatological seasonal dust AOD from each model with the range of the observational dust AOD for each region (Fig. 7b). We provide regional disaggregation of these results in Figs. 8 and 9 and summarize the seasonal observational dust AOD for each region in Table 3.

Broadly, in Fig. 7 we see that the models, except MERRAero, overestimate the amount of dust AOD over Africa with respect to the satellite estimates. The models generally overemphasize winter or spring dust at the expense of summer. This is especially the case for GEOS-Chem (highlighted in Ridley et al., 2014; see Fig. S4 therein) and for CESM, and likely a consequence of the lack of convectively driven dust emissions that will be somewhat alleviated by new parameterizations (e.g., Pantillon et al., 2016). Switching the dust scheme in GEOS-Chem to a new parameterization that does not rely on an explicit source function (Kok et al., 2014a, b) does not alleviate the seasonality issue in Africa, suggesting that the poor performance relative to the other models is likely the result of meteorology rather than the dust parameterization. Isolating the dust AOD in subregions, we find that the models overestimate dust in the North Africa, West Africa, and Bodele/Sudan regions, while better matching the dust AOD in the mid-Atlantic outflow region, although there is significant variability between the four models (see Figs. 8 and 9 for the subregions).

In the models, dust AOD over North Africa is greater than observed and dust AOD over the mid-Atlantic is often lower than observed (see Fig. 8), even when extra cloud filtering of the satellite retrievals is included. This yields a ratio of the dust AOD over Africa to that over the mid-Atlantic of $3.46 \pm 0.25$ for the models and $2.30 \pm 0.16$ based on observa-
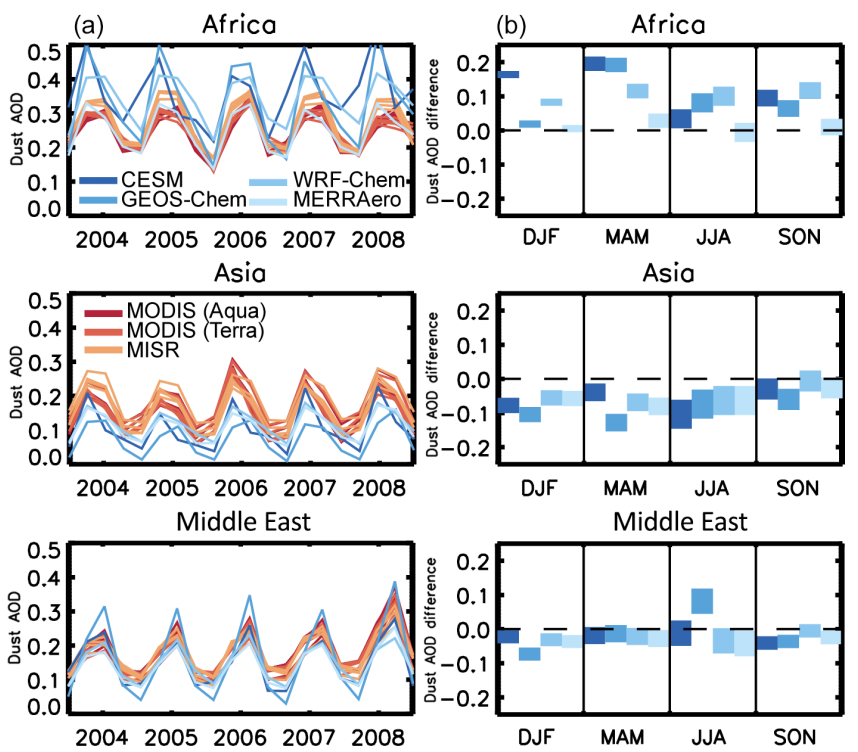

Figure 7. (a) Seasonal dust AOD between 2004 and 2008 for observational-based estimates (red hues; each of the 12 lines represents a different ensemble member) and for the models (blue hues). (b) To isolate the seasonality, the difference between model and observational-based seasonal dust AOD, averaged over 2004-2008, is shown. Bar thickness indicates the range of the observationalbased estimates for each season; the deviation from zero (dashed line) indicates the bias in model seasonal dust AOD relative to the observations. The regions are based on area-weighted averages over the subset of regions defined in Fig. 1, except Africa, which does not include the mid-Atlantic region (shown separately in Figs. 8 and 9 with other subregions).

tions ( $2.62 \pm 0.16$ and $1.63 \pm 0.08$, respectively, with cloud filtering applied). The predominant direction of long-range transport of dust is across the Atlantic; therefore, the models are likely to be removing African dust too rapidly during transport. This is unlikely to be the result of too much dust mass concentrated at large particle sizes that sediment out rapidly, based on comparison between observed and modeled size distributions (Kok, 2011a). Instead, it may stem from the vertical distribution and mixing in the planetary boundary layer that can increase dry and wet removal through proximity to the surface and co-location with precipitating clouds, respectively. Indeed, the choice of boundary layer mixing scheme can have a significant impact on long-range dust transport (Jin et al., 2015). The GEOS-Chem model dust lifetime over the Atlantic was shown to be $25-50 \%$ shorter than inferred from MODIS and primarily controlled by wet removal that dominates over dry deposition in the mid-Atlantic region (Ridley et al., 2012). It is unclear whether this bias is connected to a poor representation of the Saharan Air Layer (SAL) at present model resolution or an unidentified source of systematic bias. Higher-resolution simulations will be required to capture the structure of the SAL, which can act as a conveyor for dust across the Atlantic. Excessive re- 
Table 3. Observational estimates of the seasonal dust AOD in each region of Fig. 1, averaged over 2004-2008. The first three rows show the seasonal dust AOD for the broad regions (grouped by color in Fig. 1; Africa does not include the Gulf of Guinea region)

\begin{tabular}{lrrrr}
\hline Region & DJF & MAM & JJA & SON \\
\hline Asia & $0.114 \pm 0.017$ & $0.237 \pm 0.017$ & $0.191 \pm 0.027$ & $0.094 \pm 0.021$ \\
Middle East & $0.119 \pm 0.012$ & $0.201 \pm 0.017$ & $0.250 \pm 0.021$ & $0.129 \pm 0.014$ \\
Africa & $0.167 \pm 0.007$ & $0.291 \pm 0.012$ & $0.298 \pm 0.017$ & $0.196 \pm 0.015$ \\
Northern Africa & $0.118 \pm 0.011$ & $0.219 \pm 0.010$ & $0.207 \pm 0.016$ & $0.151 \pm 0.016$ \\
Mid-Atlantic & $0.064 \pm 0.013$ & $0.106 \pm 0.008$ & $0.143 \pm 0.005$ & $0.084 \pm 0.006$ \\
Mali/Niger & $0.257 \pm 0.019$ & $0.441 \pm 0.022$ & $0.462 \pm 0.044$ & $0.277 \pm 0.023$ \\
Bodele/Sudan & $0.191 \pm 0.006$ & $0.339 \pm 0.023$ & $0.310 \pm 0.018$ & $0.212 \pm 0.021$ \\
West coast & $0.180 \pm 0.010$ & $0.250 \pm 0.019$ & $0.365 \pm 0.016$ & $0.233 \pm 0.022$ \\
Southern Middle East & $0.123 \pm 0.018$ & $0.204 \pm 0.021$ & $0.330 \pm 0.044$ & $0.150 \pm 0.020$ \\
Kyzyl Kum & $0.115 \pm 0.017$ & $0.176 \pm 0.026$ & $0.154 \pm 0.034$ & $0.101 \pm 0.018$ \\
Northern Middle East & $0.112 \pm 0.011$ & $0.223 \pm 0.011$ & $0.164 \pm 0.015$ & $0.113 \pm 0.019$ \\
Thar & $0.130 \pm 0.029$ & $0.238 \pm 0.033$ & $0.319 \pm 0.029$ & $0.135 \pm 0.037$ \\
Gobi & $0.093 \pm 0.022$ & $0.192 \pm 0.022$ & $0.102 \pm 0.035$ & $0.047 \pm 0.021$ \\
Taklamakan & $0.119 \pm 0.013$ & $0.275 \pm 0.027$ & $0.171 \pm 0.026$ & $0.104 \pm 0.011$ \\
South Africa & $0.097 \pm 0.023$ & $0.073 \pm 0.022$ & $0.059 \pm 0.021$ & $0.114 \pm 0.040$ \\
Australia & $0.022 \pm 0.016$ & $0.008 \pm 0.009$ & $-0.005 \pm 0.008$ & $0.001 \pm 0.023$ \\
South America & $0.020 \pm 0.017$ & $0.000 \pm 0.013$ & $-0.012 \pm 0.013$ & $0.017 \pm 0.013$ \\
\hline
\end{tabular}

moval of dust will bias modeled dust lifetime low and result in a conservative observational global dust AOD estimate because of the regional-to-global scaling employed in this study. The range of model dust lifetimes results in 13 to $23 \%$ of the global dust AOD coming from regions outside of those considered explicitly in this study and constitutes a $\pm 6 \%$ (0.0018) uncertainty in the observational global dust AOD estimate (Table 1); therefore, based on the comparison of dust AOD across the mid-Atlantic it is plausible that the actual global dust AOD is towards the upper limit of this uncertainty bound. While the model representation of transport and deposition of mid-Atlantic dust may not be a major factor in the global dust AOD, it could have important implications for the simulation of hurricane genesis and nutrient deposition in the Amazon.

The models consistently underestimate AOD over Asian desert regions throughout most seasons (Fig. 8). The low bias is present across all models and in all seasons except fall, when dust AOD is relatively low. The greatest divergence between models and observations occurs in spring AOD peak at the Taklamakan desert and in summer peak in the Thar desert, located between India and Pakistan. Only CESM and MERRAero capture the seasonality in the Thar region. Enhanced summertime coarse mode AOD retrieved at AERONET sites in Karachi and Jaipur, located on either side of the Thar desert, indicates that the models are likely missing dust emissions rather than the observational estimate being biased high. The low bias in modeled dust AOD is less pronounced in the Gobi Desert, where GEOS-Chem and WRF-Chem appear to capture the observed spring peak in dust AOD. However, Fig. 8 indicates that there is consider- able uncertainty between the observational estimates in the Gobi Desert.

In the Middle East there is a slight low bias in the models relative to the observational dust AOD, through a combination of a substantial low bias in the southern Middle East region and a slightly high bias in the northern Middle East and Kyzyl Kum regions. We find general agreement between the modeled and observed seasonality, with a spring peak in the northern Middle East region and summer peaks in the southern Middle East and Kyzyl Kum regions. However, all but MERRAero overemphasize summer dust at the expense of winter in the Kyzyl Kum region. CESM produces too much dust in summer, relative to other seasons, driven by high dust AOD between the southern Middle East and Kyzyl Kum regions (the Gulf of Oman) that is present, but weaker, in the satellite observations.

Considering the southern hemispheric regions, our analysis indicates that the simulated dust AOD is comparable in Australia and lower than observed in South Africa and South America. However, the uncertainty in the observational dust AOD is too large to draw quantitative conclusions about the model representation of dust in those regions.

Throughout the comparison we find that MERRAero generally provides dust AOD that agrees better with the observational estimates, both in seasonality and magnitude, relative to the other models. This is expected as the MERRAero simulation involves assimilation of MODIS AOD retrievals (Buchard et al., 2015) and is therefore not independent from the observations to which we are comparing. Furthermore, MERRAero is also produced at a higher resolution than the other models $\left(0.625^{\circ} \times 0.5^{\circ}\right)$, which may further contribute to better representation of dust emissions due to more spa- 

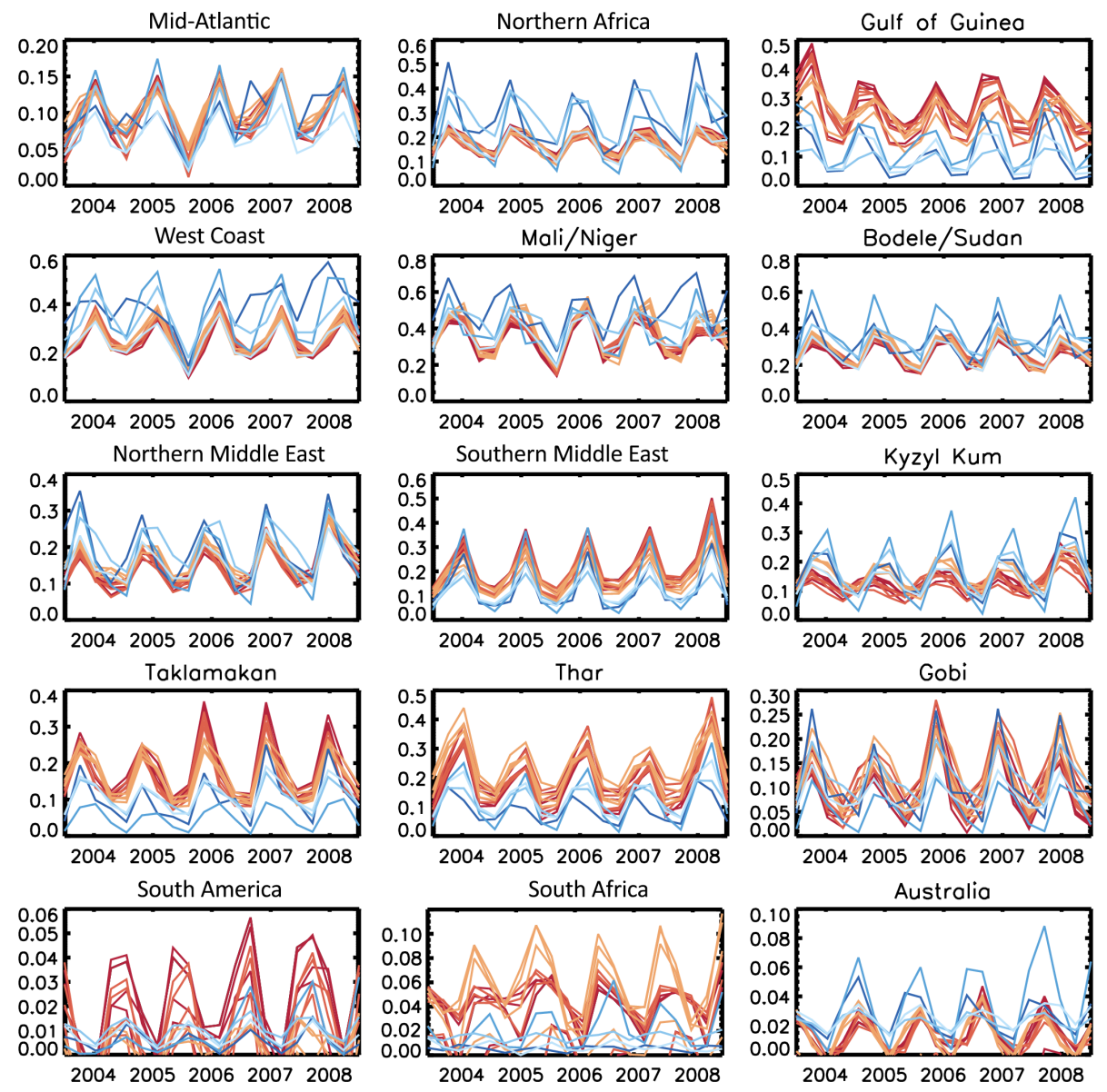

Figure 8. Same as Fig. 7a but for each individual region (in Fig. 1). Observational dust AOD is shown for multiple realizations of MODIS Aqua, MODIS Terra, and MISR (dark to light red). Models are GEOS-Chem, CESM, WRF-Chem, and MERRAero (dark to light blue).

tially resolved surface winds. However, the magnitude of the global dust AOD provided by the MERRAero simulation is the lowest of the four models (0.027) and is 0.003 lower than the observationally constrained estimate presented here (within the $1 \sigma$ uncertainty bound). The total global AOD for all species in MERRAero is $5-15 \%$ higher than the other models, while dust accounts for a smaller fraction of the AOD in MERRAero (20\%) than the other models (24$26 \%$ ). This can be interpreted in two ways: either the contribution of dust to the total AOD is conservative in MERRAero or the observationally constrained estimates of dust AOD are biased high due to a persistent low bias of non-dust AOD in three of the four models.

\subsection{Discussion of the remaining uncertainties}

We endeavored to account for the uncertainties and biases involved in estimating the global dust AOD from observations; however, uncertainties remain that are difficult to quantify within this study. Potential sources of bias stem from (1) the model non-dust AOD, (2) the model regional-to-global AOD scaling, and (3) treatment of particle morphology and min- eralogy in models and in the satellite retrievals. These may present additional biases in the observational estimate and contribute to the discrepancies between models and observations.

We use multiple models to represent the uncertainty in non-dust AOD. However, the non-dust AOD in all models may be systematically biased high or low, which would bias the observational estimate of the dust AOD low or high, respectively. Comparison between modeled and observed AOD at the AERONET sites and MAN ship locations does suggest a low bias in the modeled total AOD in some of the regions considered, although there is no clear systematic bias in the models (see Figs. S5-S9). Comparison of model and AERONET AOD in low and high dust cases (using the model dust AOD to discriminate) suggests that two of the models are biased high and two biased low (Fig. S4). Overall, the ensemble of models appears to underestimate the non-dust AOD; correcting this results in a $7 \%$ decrease in the global dust AOD estimate (0.028). However, the uncertainties involved in this method are such that we do not include the bias correction in our final estimate (see Supplement). 

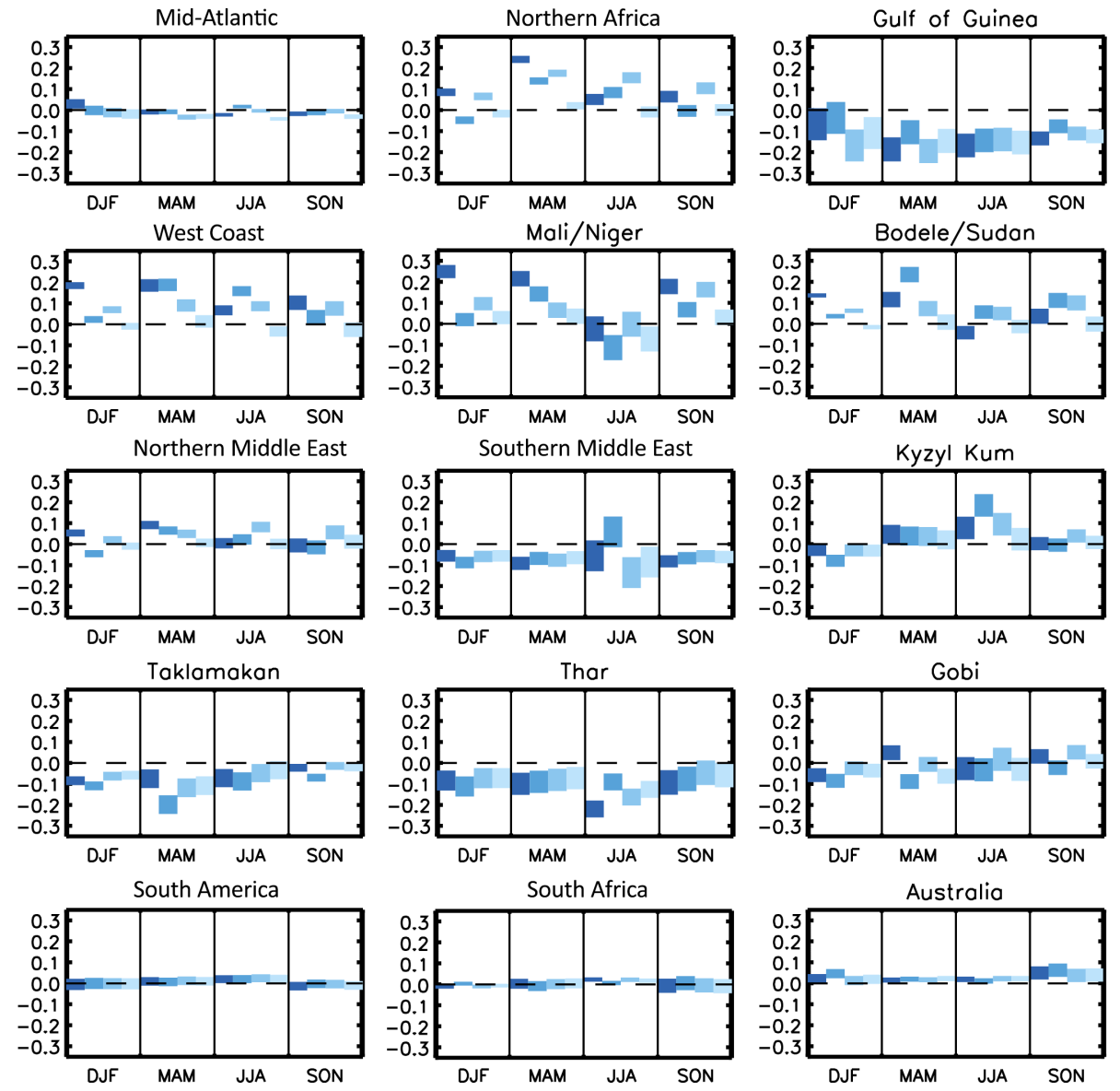

Figure 9. Same as Fig. 7b but for individual regions (in Fig. 1). Models are GEOS-Chem, CESM, WRF-Chem, and MERRAero (dark to light blue).

Modeled dust AOD is used as a scaling factor to determine the global dust AOD from the regional observational estimates. We use multiple models to represent the uncertainty, but there may be a systematic bias present, rather than the $\pm 6 \%$ uncertainty presented (Table 2 ). If the overzealous removal of dust in models, highlighted in the mid-Atlantic, is a global phenomenon then the models would predict too much dust in the source regions relative to downwind and yield a low regional-to-global scaling factor. Similarly, dust emissions schemes currently used in the models are unlikely to reproduce emissions where vegetation cover is variable and will not represent dust from agricultural regions (Ginoux et al., 2012). If those emissions are substantial, then it is possible that tuned emissions in models overestimate emissions from large, permanent dust sources to compensate for the lack of agricultural emissions, which could partially explain model bias towards African emissions.

Some of the discrepancy between the dust AOD from models and observations is likely born out of simplifications in representing particle morphology and mineralogy and the resulting impact on the AOD. The models in this study assume a globally fixed refractive index for dust and either spherical or spheroid particle shapes. We do not quantify the uncertainty from mineralogy and morphology here; however, several studies have shown the influence of refractive index and shape upon the derived optical and radiative properties (e.g., Balkanski et al., 2007; Kalashnikova and Sokolik, 2004; Scanza et al., 2015). Scanza et al. (2015) estimate a reduction of approximately $6 \%$ on the global dust AOD when accounting for spatially varying mineralogy in the Community Atmosphere Model (CAM-5). Particle morphology and mineralogy may also present a general bias in AOD retrievals as well as the models. Simplified particle shape modeling during retrieval has been shown to cause underestimation of AOD from space-based retrievals and overestimation from ground-based observations (Kalashnikova and Sokolik, 2002). Similarly, strongly absorbing dust can result in underestimation of the AOD, although improvements in MODIS Collection 6 have been shown to alleviate this (Hsu et al., 2013). The impact on the observational estimate of dust AOD will be dependent upon the specific assumptions made by the MODIS and MISR retrievals, both of which take particle nonsphericity into account but using different methodologies (see Sect. 2.1 and 2.2 and references therein). Finally, poten- 
tial biases exist via erroneous filtering of thick dust plumes during the retrieval (Baddock et al., 2016).

\section{Conclusions}

To provide an observational constraint for the global dust AOD we use three satellite retrievals of AOD over a 5-year period, AERONET observations to correct biases in the satellite retrievals, and speciated aerosol AOD from four global chemical transport models to separate the contributions of dust and non-dust AOD. Throughout the analysis we use bootstrapping to retain a robust estimate of the uncertainty on the dust AOD. We determine the global dust AOD to be $0.030 \pm 0.005(1 \sigma)$, with nearly three-quarters $(73 \%)$ of the ensemble members in this study yielding a larger dust AOD than the mean of the 15 AeroCom models $(0.028 \pm 0.011)$ and all combinations greater than the AeroCom model median (0.023). The observational estimate narrows the likely range of dust AOD by half from that presented by the model estimates. The observational dust AOD is constructed as seasonal averages for 5 years (2004-2008) across 15 regions, providing a dataset with which the broad performance of model dust schemes can be evaluated (summarized in Table 3, with further data available by request to the author).

All four models used in this study are within the one standard deviation uncertainty of the global mean observational estimate. However, it is essential to evaluate models on regional and seasonal scales, at which we find considerable differences. Using the regional and seasonal estimates of dust AOD, we highlight four general discrepancies between the models and observations: (1) the dust AOD across most of North Africa is overestimated in the models; (2) the Asian and Middle Eastern deserts are underrepresented overall; (3) modeled seasonality varies considerably between models, but it generally overestimates winter and spring dust at the expense of summer in Africa and overestimate fall dust at the expense of spring in Asian deserts; and (4) removal of dust exported across the Atlantic appears to be too strong in the models, which may indicate a systematic underestimation of dust lifetimes. We have used the observationally constrained estimate of dust AOD to isolate specific regions in which the models disagree with the observations; however, the underlying mechanisms for the discrepancies are unclear and may be driven by the assumed physical characteristics of the surface, by the representation of surface wind, by the subsequent transport and deposition, or likely a combination of all factors. Further research in the areas highlighted in this work is expected to improve model simulations, and hence future estimates of the radiative, human health, and biosphere interactions of mineral dust.

\section{Data availability}

The GEOS-Chem, WRF-Chem, CESM and MERRAero data used in this study are archived at MIT and available on request from the lead author (daridley@mit.edu). The MERRAero speciated aerosol optical depth product can be downloaded from (MERRAero, 2015). The MODIS and MISR Level 3 daily products are available from https: //ladsweb.nascom.nasa.gov/search/ (MODIS, 2015) and https://www-misr.jpl.nasa.gov/getData/accessData/ (MISR, 2015), respectively. AERONET data can be browsed and downloaded from http://aeronet.gsfc.nasa.gov/ (AERONET, 2015) and the Maritime Aerosol Network data is available at http://aeronet.gsfc.nasa.gov/new_web/maritime_aerosol_ network.html (Smirnov et al., 2009).

\section{The Supplement related to this article is available online at doi:10.5194/acp-16-15097-2016-supplement.}

Acknowledgements. This work was supported by NASA under grant NN14AP38G. Jasper F. Kok acknowledges support from the National Science Foundation (NSF) under grant 1552519. Chun Zhao is supported by the US Department of Energy (DOE) as part of the Regional \& Global Climate Modeling (RGCM) program.

Edited by: Y. Balkanski

Reviewed by: A. Evan and four anonymous referees

\section{References}

AERONET: Level 2 "all points" aerosol optical depth, NASA Goddard Space Flight Center, available at: http://aeronet.gsfc.nasa. gov/, last access: May 2015.

Albani, S., Mahowald, N. M., Perry, A. T., Scanza, R. A., Zender, C. S., Heavens, N. G., Maggi, V., Kok, J. F., and OttoBliesner, B. L.: Improved dust representation in the Community Atmosphere Model, J. Adv. Model. Earth Syst., 6, 541-570, doi:10.1002/2013MS000279, 2014.

Alexander, B., Park, R. J., Jacob, D. J., Li, Q. B., Yantosca, R. M., Savarino, J., Lee, C. C. W., and Thiemens, M. H.: Sulfate formation in sea-salt aerosols: Constraints from oxygen isotopes, J. Geophys. Res.-Atmos., 110, D10307, doi:10.1029/2004JD005659, 2005.

Ångström, A.: The parameters of atmospheric turbidity, Tellus, 16, 64-75, doi:10.1111/j.2153-3490.1964.tb00144.x, 1964.

Baddock, M. C., Ginoux, P., Bullard, J. E., and Gill, T. E.: Do MODIS-defined dust sources have a geomorphological signature?, Geophys. Res. Lett., 43, GL067327, doi:10.1002/2015GL067327, 2016.

Balkanski, Y., Schulz, M., Claquin, T., and Guibert, S.: Reevaluation of Mineral aerosol radiative forcings suggests a better agreement with satellite and AERONET data, Atmos. Chem. Phys., 7, 81-95, doi:10.5194/acp-7-81-2007, 2007. 
Barnard, J. C., Fast, J. D., Paredes-Miranda, G., Arnott, W. P., and Laskin, A.: Technical Note: Evaluation of the WRF-Chem "Aerosol Chemical to Aerosol Optical Properties" Module using data from the MILAGRO campaign, Atmos. Chem. Phys., 10, 7325-7340, doi:10.5194/acp-10-7325-2010, 2010.

Boucher, O., Randall, D., Artaxo, P., Bretherton, C., Feingold, G., Forster, P., Kerminen, V.-M., Kondo, Y., Liao, H., and Lohmann, U.: Clouds and aerosols, in Climate change 2013: The physical science basis, Contribution of working group I to the fifth assessment report of the intergovernmental panel on climate change, Cambridge University Press, 571-657, 2013.

Buchard, V., da Silva, A. M., Colarco, P., Krotkov, N., Dickerson, R. R., Stehr, J. W., Mount, G., Spinei, E., Arkinson, H. L., and He, H.: Evaluation of GEOS-5 sulfur dioxide simulations during the Frostburg, MD 2010 field campaign, Atmos. Chem. Phys., 14, 1929-1941, doi:10.5194/acp-14-1929-2014, 2014.

Buchard, V., Silva, A. M. da, Colarco, P. R., Darmenov, A., Randles, C. A., Govindaraju, R., Torres, O., Campbell, J., and Spurr, R.: Using the OMI aerosol index and absorption aerosol optical depth to evaluate the NASA MERRA Aerosol Reanalysis, Atmos. Chem. Phys., 15, 5743-5760, doi:10.5194/acp-15-57432015, 2015.

Buchard, V., da Silva, A. M., Randles, C. A., Colarco, P., Ferrare, R., Hair, J., Hostetler, C., Tackett, J., and Winker, D.: Evaluation of the surface PM2.5 in Version 1 of the NASA MERRA Aerosol Reanalysis over the United States, Atmos. Environ. Pt. A,, 125, 100-111, doi:10.1016/j.atmosenv.2015.11.004, 2016.

Cakmur, R. V., Miller, R. L., Perlwitz, J., Geogdzhayev, I. V., Ginoux, P., Koch, D., Kohfeld, K. E., Tegen, I., and Zender, C. S.: Constraining the magnitude of the global dust cycle by minimizing the difference between a model and observations, J. Geophys. Res.-Atmos., 111, D06207, doi:10.1029/2005JD005791, 2006.

Chin, M., Ginoux, P., Kinne, S., Torres, O., Holben, B. N., Duncan, B. N., Martin, R. V., Logan, J. A., Higurashi, A., and Nakajima, T.: Tropospheric aerosol optical thickness from the GOCART model and comparisons with satellite and Sun photometer measurements, J. Atmos. Sci., 59, 461-483, 2002.

Colarco, P., da Silva, A., Chin, M., and Diehl, T.: Online simulations of global aerosol distributions in the NASA GEOS-4 model and comparisons to satellite and ground-based aerosol optical depth, J. Geophys. Res.-Atmos., 115, D14207, doi:10.1029/2009JD012820, 2010.

Darmenov, A. and Sokolik, I. N.: Spatial variability of satellite visible radiances in dust and dust-cloud mixed conditions: Implications for dust detection, Geophys. Res. Lett., 36, L14811, doi:10.1029/2009GL038383, 2009.

Dee, D. P., Uppala, S. M., Simmons, A. J., Berrisford, P., Poli, P., Kobayashi, S., Andrae, U., Balmaseda, M. A., Balsamo, G., Bauer, P., Bechtold, P., Beljaars, A. C. M., van de Berg, L., Bidlot, J., Bormann, N., Delsol, C., Dragani, R., Fuentes, M., Geer, A. J., Haimberger, L., Healy, S. B., Hersbach, H., Hólm, E. V., Isaksen, L., Kållberg, P., Köhler, M., Matricardi, M., McNally, A. P., Monge-Sanz, B. M., Morcrette, J.-J., Park, B.-K., Peubey, C., de Rosnay, P., Tavolato, C., Thépaut, J.-N., and Vitart, F.: The ERA-Interim reanalysis: configuration and performance of the data assimilation system, Q. J. R. Meteorol. Soc., 137, 553-597, doi:10.1002/qj.828, 2011.

Drury, E., Jacob, D. J., Spurr, R. J. ., Wang, J., Shinozuka, Y., Anderson, B. E., Clarke, A. D., Dibb, J., McNaughton, C., and Weber,
R.: Synthesis of satellite (MODIS), aircraft (ICARTT), and surface (IMPROVE, EPA-AQS, AERONET) aerosol observations over eastern North America to improve MODIS aerosol retrievals and constrain surface aerosol concentrations and sources, J. Geophys. Res., 115, D14204, doi:10.1029/2009JD012629, 2010.

Eck, T. F., Holben, B. N., Reid, J. S., Dubovik, O., Smirnov, A., O’Neill, N. T., Slutsker, I., and Kinne, S.: Wavelength dependence of the optical depth of biomass burning, urban, and desert dust aerosols, J. Geophys. Res.-Atmos., 104, 3133331349, doi:10.1029/1999JD900923, 1999.

Eck, T. F., Holben, B. N., Reid, J. S., Arola, A., Ferrare, R. A., Hostetler, C. A., Crumeyrolle, S. N., Berkoff, T. A., Welton, E. J., Lolli, S., Lyapustin, A., Wang, Y., Schafer, J. S., Giles, D. M., Anderson, B. E., Thornhill, K. L., Minnis, P., Pickering, K. E., Loughner, C. P., Smirnov, A., and Sinyuk, A.: Observations of rapid aerosol optical depth enhancements in the vicinity of polluted cumulus clouds, Atmos. Chem. Phys., 14, 11633-11656, doi:10.5194/acp-14-11633-2014, 2014.

Efron, B. and Gong, G.: A Leisurely Look at the Bootstrap, the Jackknife, and Cross-Validation, Am. Stat., 37, 36-48, doi:10.1080/00031305.1983.10483087, 1983.

Emmons, L. K., Walters, S., Hess, P. G., Lamarque, J.-F., Pfister, G. G., Fillmore, D., Granier, C., Guenther, A., Kinnison, D., Laepple, T., Orlando, J., Tie, X., Tyndall, G., Wiedinmyer, C., Baughcum, S. L., and Kloster, S.: Description and evaluation of the Model for Ozone and Related chemical Tracers, version 4 (MOZART-4), Geosci. Model Dev., 3, 43-67, doi:10.5194/gmd3-43-2010, 2010.

Evan, A. T., Flamant, C., Fiedler, S., and Doherty, O.: An analysis of aeolian dust in climate models, Geophys. Res. Lett., 41, GL060545, doi:10.1002/2014GL060545, 2014.

Evans, J., van Donkelaar, A., Martin, R. V., Burnett, R., Rainham, D. G., Birkett, N. J., and Krewski, D.: Estimates of global mortality attributable to particulate air pollution using satellite imagery, Environ. Res., 120, 33-42, doi:10.1016/j.envres.2012.08.005, 2013.

Fairlie, T. D., Jacob, D. J., and Park, R. J.: The impact of transpacific transport of mineral dust in the United States, Atmos. Environ. 41, 1251-1266, 2007.

Fast, J. D., Gustafson, W. I., Easter, R. C., Zaveri, R. A., Barnard, J. C., Chapman, E. G., Grell, G. A., and Peckham, S. E.: Evolution of ozone, particulates, and aerosol direct radiative forcing in the vicinity of Houston using a fully coupled meteorology-chemistry-aerosol model, J. Geophys. Res.-Atmos., 111, D21305, doi:10.1029/2005JD006721, 2006.

Ford, B. and Heald, C. L.: Exploring the uncertainty associated with satellite-based estimates of premature mortality due to exposure to fine particulate matter, Atmos. Chem. Phys., 16, 3499-3523, doi:10.5194/acp-16-3499-2016, 2016.

Fountoukis, C. and Nenes, A.: ISORROPIA II: a computationally efficient thermodynamic equilibrium model for $\mathrm{K}^{+}$ $\mathrm{Ca}_{2}^{+}-\mathrm{Mg}_{2}^{+}-\mathrm{NH}_{4}^{+}-\mathrm{Na}^{+}-\mathrm{SO}_{4}^{2-}-\mathrm{NO}_{3}-\mathrm{Cl}-\mathrm{H}_{2} \mathrm{O}$ aerosols, Atmos. Chem. Phys., 7, 4639-4659, doi:10.5194/acp-7-4639-2007, 2007.

French, N. H. F., Goovaerts, P., and Kasischke, E. S.: Uncertainty in estimating carbon emissions from boreal forest fires, J. Geophys. Res.-Atmos., 109, D14S08, doi:10.1029/2003JD003635, 2004.

Ginoux, P., Chin, M., Tegen, I., Prospero, J. M., Holben, B., Dubovik, O., and Lin, S.-J.: Sources and distributions of dust 
aerosols simulated using the GOCART model, J. Geophys. Res., 106, 20255-20273, 2001.

Ginoux, P., Prospero, J. M., Gill, T. E., Hsu, N. C., and Zhao, M.: Global-scale attribution of anthropogenic and natural dust sources and their emission rates based on MODIS Deep Blue aerosol products, Rev. Geophys., 50, doi:10.1029/2012RG000388, 2012.

Gong, S.: A parameterization of sea-salt aerosol source function for sub- and super-micron particles, Global Biochem. Cy., 17, 1097, 2003.

Heald, C. L. and Spracklen, D. V.: Land Use Change Impacts on Air Quality and Climate, Chem. Rev., 115, 4476-4496, doi:10.1021/cr500446g, 2015.

Heald, C. L., Ridley, D. A., Kroll, J. H., Barrett, S. R. H., CadyPereira, K. E., Alvarado, M. J., and Holmes, C. D.: Contrasting the direct radiative effect and direct radiative forcing of aerosols, Atmos. Chem. Phys., 14, 5513-5527, doi:10.5194/acp-14-55132014, 2014.

Hess, M., Koepke, P., and Schult, I.: Optical propeties of aerosol and clouds: The software package OPAC, Bull. Am. Meteorol. Soc., 79, 831-844, 1998a.

Hess, M., Koepke, P., and Schult, I.: Optical propeties of aerosol and clouds: The software package OPAC, Bull. Am. Meteorol. Soc., 79, 831-844, 1998b.

Holben, B. N., Eck, T. F., Slutsker, I., Tanré, D., Buis, J. P., Setzer, A., Vermote, E., Reagan, J. A., Kaufman, Y. J., Nakajima, T., Lavenu, F., Jankowiak, I., and Smirnov, A.: AERONET-A Federated Instrument Network and Data Archive for Aerosol Characterization, Remote Sens. Environ., 66, 1-16, doi:10.1016/S0034-4257(98)00031-5, 1998.

Hsu, N. C., Tsay, S.-C., King, M. D., and Herman, J. R.: Aerosol properties over bright-reflecting source regions, IEEE Trans. Geosci. Remote Sens., 42, 557-569, doi:10.1109/TGRS.2004.824067, 2004.

Hsu, N. C., Tsay, S. C., King, M. D., and Herman, J. R.: Deep blue retrievals of Asian aerosol properties during ACEAsia, IEEE Trans. Geosci. Remote Sens., 44, 3180-3195, doi:10.1109/tgrs.2006.879540, 2006.

Hsu, N. C., Jeong, M.-J., Bettenhausen, C., Sayer, A. M., Hansell, R., Seftor, C. S., Huang, J., and Tsay, S.-C.: Enhanced Deep Blue aerosol retrieval algorithm: The second generation, J. Geophys. Res.-Atmos., 118, 9296-9315, doi:10.1002/jgrd.50712, 2013.

Hu, Z., Zhao, C., Huang, J., Leung, L. R., Qian, Y., Yu, H., Huang, L., and Kalashnikova, O. V.: Trans-Pacific transport and evolution of aerosols: evaluation of quasi-global WRF-Chem simulation with multiple observations, Geosci. Model Dev., 9, 17251746, doi:10.5194/gmd-9-1725-2016, 2016.

Huneeus, N., Schulz, M., Balkanski, Y., Griesfeller, J., Prospero, J., Kinne, S., Bauer, S., Boucher, O., Chin, M., Dentener, F., Diehl, T., Easter, R., Fillmore, D., Ghan, S., Ginoux, P., Grini, A., Horowitz, L., Koch, D., Krol, M. C., Landing, W., Liu, X., Mahowald, N., Miller, R., Morcrette, J.-J., Myhre, G., Penner, J., Perlwitz, J., Stier, P., Takemura, T., and Zender, C. S.: Global dust model intercomparison in AeroCom phase I, Atmos. Chem. Phys., 11, 7781-7816, doi:10.5194/acp-11-7781-2011, 2011.

Hurrell, J. W.: 2011 Community Earth System Model (cesm) Tutorial, 1-5 August 2011, University Corporation for Atmospheric Research, available at: http://www.osti.gov/scitech/ biblio/1096191 (last access: 7 April 2016), 2013.
Jaeglé, L., Quinn, P. K., Bates, T. S., Alexander, B., and Lin, J.-T.: Global distribution of sea salt aerosols: new constraints from in situ and remote sensing observations, Atmos. Chem. Phys., 11, 3137-3157, doi:10.5194/acp-11-3137-2011, 2011.

Jin, Q., Wei, J., Yang, Z.-L., Pu, B., and Huang, J.: Consistent response of Indian summer monsoon to Middle East dust in observations and simulations, Atmos. Chem. Phys., 15, 9897-9915, doi:10.5194/acp-15-9897-2015, 2015.

Kahn, R. A., Gaitley, B. J., Garay, M. J., Diner, D. J., Eck, T. F., Smirnov, A., and Holben, B. N.: Multiangle Imaging SpectroRadiometer global aerosol product assessment by comparison with the Aerosol Robotic Network, J. Geophys. Res.-Atmos., 115, D23209, doi:10.1029/2010jd014601, 2010.

Kalashnikova, O. V. and Sokolik, I. N.: Importance of shapes and compositions of wind-blown dust particles for remote sensing at solar wavelengths, Geophys. Res. Lett., 29, 38-1-38-4, doi:10.1029/2002GL014947, 2002.

Kalashnikova, O. V. and Sokolik, I. N.: Modeling the radiative properties of nonspherical soil-derived mineral aerosols, J. Quant. Spectrosc. Ra., 87, 137-166, doi:10.1016/j.jqsrt.2003.12.026, 2004.

Kalashnikova, O. V., Kahn, R., Sokolik, I. N., and Li, W.-H.: Ability of multiangle remote sensing observations to identify and distinguish mineral dust types: Optical models and retrievals of optically thick plumes, J. Geophys. Res.-Atmos., 110, D18S14, doi:10.1029/2004JD004550, 2005.

Kok, J. F.: A scaling theory for the size distribution of emitted dust aerosols suggests climate models underestimate the size of the global dust cycle, P. Natl. Acad. Sci., 108, 1016-1021, 2011a.

Kok, J. F.: Does the size distribution of mineral dust aerosols depend on the wind speed at emission?, Atmos. Chem. Phys., 11, 1014910156, doi:10.5194/acp-11-10149-2011, 2011 b.

Kok, J. F., Parteli, E. J. R., Michaels, T. I., and Karam, D. B.: The physics of wind-blown sand and dust, Rep. Prog. Phys., 75, 106901, doi:10.1088/0034-4885/75/10/106901, 2012.

Kok, J. F., Mahowald, N. M., Fratini, G., Gillies, J. A., Ishizuka, M., Leys, J. F., Mikami, M., Park, M.-S., Park, S.-U., Van Pelt, R. S., and Zobeck, T. M.: An improved dust emission model - Part 1: Model description and comparison against measurements, Atmos. Chem. Phys., 14, 13023-13041, doi:10.5194/acp14-13023-2014, 2014a.

Kok, J. F., Albani, S., Mahowald, N. M., and Ward, D. S.: An improved dust emission model - Part 2: Evaluation in the Community Earth System Model, with implications for the use of dust source functions, Atmos. Chem. Phys., 14, 13043-13061, doi:10.5194/acp-14-13043-2014, 2014b.

Kok, J. F., Ridley, D. A., Zhou, Q., Zhao, C., Miller, R. L., Heald, C. L., and Haustein, K.: Integrative analysis of desert dust size and abundance suggests less dust climate cooling, Nat. Geosci., in review, 2016.

Koren, I., Remer, L. A., Kaufman, Y. J., Rudich, Y., and Martins, J. V.: On the twilight zone between clouds and aerosols, Geophys. Res. Lett., 34, L08805, doi:10.1029/2007GL029253, 2007.

Lamarque, J.-F., Emmons, L. K., Hess, P. G., Kinnison, D. E., Tilmes, S., Vitt, F., Heald, C. L., Holland, E. A., Lauritzen, P. H., Neu, J., Orlando, J. J., Rasch, P. J., and Tyndall, G. K.: CAM-chem: description and evaluation of interactive atmospheric chemistry in the Community Earth System Model, 
Geosci. Model Dev., 5, 369-411, doi:10.5194/gmd-5-369-2012, 2012.

Leibensperger, E. M., Mickley, L. J., Jacob, D. J., Chen, W.-T., Seinfeld, J. H., Nenes, A., Adams, P. J., Streets, D. G., Kumar, N., and Rind, D.: Climatic effects of 1950-2050 changes in US anthropogenic aerosols - Part 1: Aerosol trends and radiative forcing, Atmos. Chem. Phys., 12, 3333-3348, doi:10.5194/acp-12-33332012, 2012.

Levy, R. C., Remer, L. A., Kleidman, R. G., Mattoo, S., Ichoku, C., Kahn, R., and Eck, T. F.: Global evaluation of the Collection 5 MODIS dark-target aerosol products over land, Atmos. Chem. Phys., 10, 10399-10420, doi:10.5194/acp-10-10399-2010, 2010.

Levy, R. C., Mattoo, S., Munchak, L. A., Remer, L. A., Sayer, A. M., Patadia, F., and Hsu, N. C.: The Collection 6 MODIS aerosol products over land and ocean, Atmos. Meas. Tech., 6, 29893034, doi:10.5194/amt-6-2989-2013, 2013.

Lim, S. S., Vos, T., Flaxman, A. D., Danaei, G., Shibuya, K., AdairRohani, H., AlMazroa, M. A., Amann, M., Anderson, H. R., Andrews, K. G., Aryee, M., Atkinson, C., Bacchus, L. J., Bahalim, A. N., Balakrishnan, K., Balmes, J., Barker-Collo, S., Baxter, A., Bell, M. L., Blore, J. D., Blyth, F., Bonner, C., Borges, G., Bourne, R., Boussinesq, M., Brauer, M., Brooks, P., Bruce, N. G., Brunekreef, B., Bryan-Hancock, C., Bucello, C., Buchbinder, R., Bull, F., Burnett, R. T., Byers, T. E., Calabria, B., Carapetis, J., Carnahan, E., Chafe, Z., Charlson, F., Chen, H., Chen, J. S., Cheng, A. T.-A., Child, J. C., Cohen, A., Colson, K. E., Cowie, B. C., Darby, S., Darling, S., Davis, A., Degenhardt, L., Dentener, F., Des Jarlais, D. C., Devries, K., Dherani, M., Ding, E. L., Dorsey, E. R., Driscoll, T., Edmond, K., Ali, S. E., Engell, R. E., Erwin, P. J., Fahimi, S., Falder, G., Farzadfar, F., Ferrari, A., Finucane, M. M., Flaxman, S., Fowkes, F. G. R., Freedman, G., Freeman, M. K., Gakidou, E., Ghosh, S., Giovannucci, E., Gmel, G., Graham, K., Grainger, R., Grant, B., Gunnell, D., Gutierrez, H. R., Hall, W., Hoek, H. W., Hogan, A., Hosgood III, H. D., Hoy, D., Hu, H., Hubbell, B. J., Hutchings, S. J., Ibeanusi, S. E., Jacklyn, G. L., Jasrasaria, R., Jonas, J. B., Kan, H., Kanis, J. A., Kassebaum, N., Kawakami, N., Khang, Y.-H., Khatibzadeh, S., Khoo, J.-P., et al.: A comparative risk assessment of burden of disease and injury attributable to 67 risk factors and risk factor clusters in 21 regions, 1990-2010: a systematic analysis for the Global Burden of Disease Study 2010, The Lancet, 380, 22242260, doi:10.1016/S0140-6736(12)61766-8, 2012.

Liu, X., Easter, R. C., Ghan, S. J., Zaveri, R., Rasch, P., Shi, X., Lamarque, J.-F., Gettelman, A., Morrison, H., Vitt, F., Conley, A., Park, S., Neale, R., Hannay, C., Ekman, A. M. L., Hess, P., Mahowald, N., Collins, W., Iacono, M. J., Bretherton, C. S., Flanner, M. G., and Mitchell, D.: Toward a minimal representation of aerosols in climate models: description and evaluation in the Community Atmosphere Model CAM5, Geosci. Model Dev., 5, 709-739, doi:10.5194/gmd-5-709-2012, 2012.

Lu, Z., Zhang, Q., and Streets, D. G.: Sulfur dioxide and primary carbonaceous aerosol emissions in China and India, 1996-2010, Atmos. Chem. Phys., 11, 9839-9864, doi:10.5194/acp-11-98392011, 2011.

Mahowald, N. M., Muhs, D. R., Levis, S., Rasch, P. J., Yoshioka, M., Zender, C. S., and Luo, C.: Change in atmospheric mineral aerosols in response to climate: Last glacial period, preindustrial, modern, and doubled carbon dioxide climates, J. Geophys. Res.Atmos., 111, D10202, doi:10.1029/2005JD006653, 2006.
Mahowald, N. M., Kloster, S., Engelstaedter, S., Moore, J. K., Mukhopadhyay, S., McConnell, J. R., Albani, S., Doney, S. C., Bhattacharya, A., Curran, M. A. J., Flanner, M. G., Hoffman, F. M., Lawrence, D. M., Lindsay, K., Mayewski, P. A., Neff, J., Rothenberg, D., Thomas, E., Thornton, P. E., and Zender, C. S.: Observed 20th century desert dust variability: impact on climate and biogeochemistry, Atmos. Chem. Phys., 10, 10875-10893, doi:10.5194/acp-10-10875-2010, 2010.

Mann, G. W., Carslaw, K. S., Reddington, C. L., Pringle, K. J., Schulz, M., Asmi, A., Spracklen, D. V., Ridley, D. A., Woodhouse, M. T., Lee, L. A., Zhang, K., Ghan, S. J., Easter, R. C., Liu, X., Stier, P., Lee, Y. H., Adams, P. J., Tost, H., Lelieveld, J., Bauer, S. E., Tsigaridis, K., van Noije, T. P. C., Strunk, A., Vignati, E., Bellouin, N., Dalvi, M., Johnson, C. E., Bergman, T., Kokkola, H., von Salzen, K., Yu, F., Luo, G., Petzold, A., Heintzenberg, J., Clarke, A., Ogren, J. A., Gras, J., Baltensperger, U., Kaminski, U., Jennings, S. G., O’Dowd, C. D., Harrison, R. M., Beddows, D. C. S., Kulmala, M., Viisanen, Y., Ulevicius, V., Mihalopoulos, N., Zdimal, V., Fiebig, M., Hansson, H.-C., Swietlicki, E., and Henzing, J. S.: Intercomparison and evaluation of global aerosol microphysical properties among AeroCom models of a range of complexity, Atmos. Chem. Phys., 14, 4679-4713, doi:10.5194/acp-14-4679-2014, 2014.

Marshak, A., Wen, G., Coakley, J. A., Remer, L. A., Loeb, N. G., and Cahalan, R. F.: A simple model for the cloud adjacency effect and the apparent bluing of aerosols near clouds, J. Geophys. Res.-Atmos., 113, D14S17, doi:10.1029/2007JD009196, 2008.

Martin, R. V., Jacob, D. J., Yantosca, R. M., Chin, M., and Ginoux, P.: Global and regional decreases in tropospheric oxidants from photochemical effects of aerosols, J. Geophys. Res.-Atmos., 108, 4097, doi:10.1029/2002JD002622, 2003.

Martonchik, J. V., Diner, D. J., Kahn, R. A., Ackerman, T. P., Verstraete, M. E., Pinty, B., and Gordon, H. R.: Techniques for the retrieval of aerosol properties over land and ocean using multiangle imaging, IEEE Trans. Geosci. Remote Sens., 36, 1212-1227, 1998.

Martonchik, J. V., Diner, D. J., Kahn, R., Gaitley, B., and Holben, B. N.: Comparison of MISR and AERONET aerosol optical depths over desert sites, Geophys. Res. Lett., 31, L16102, doi:10.1029/2004g1019807, 2004.

Martonchik, J. V., Kahn, R. A., and Diner, D. J.: Retrieval of aerosol properties over land using MISR observations, in: Satellite Aerosol Remote Sensing over Land, edited by: Kokhanovsky, D. A. A. and de Leeuw, P. G., Springer Berlin Heidelberg, 267-293, available at: http://link.springer.com/chapter/10.1007/ 978-3-540-69397-0_9 (last access: 26 October 2016), 2009.

Matichuk, R. I., Colarco, P. R., Smith, J. A., and Toon, O. B.: Modeling the transport and optical properties of smoke aerosols from African savanna fires during the Southern African Regional Science Initiative campaign (SAFARI 2000), J. Geophys. Res.Atmos., 112, D08203, doi:10.1029/2006JD007528, 2007.

MERRAero: 2D 3-hourly primary aerosol diagnostic product, tavg3hr_2d_aer_Nx, Global Modeling and Assimilation Office, NASA Goddard Space Flight Center, available at: https://cds. nccs.nasa.gov/merra/, last access: June 2015.

Mishra, S. K., Dey, S., and Tripathi, S. N.: Implications of particle composition and shape to dust radiative effect: A case study from the Great Indian Desert, Geophys. Res. Lett., 35, L23814, doi:10.1029/2008GL036058, 2008. 
MISR: Terra MIL3DAE Level 3 daily gridded aerosol optical depth, NASA Jet Propulsion Laboratory, California Institute of Technology, available at: https://eosweb.larc.nasa.gov, last access: November 2015.

MODIS: Terra MOD08_D3 and Aqua MYD08_D3 Level 3 daily gridded aerosol optical depth, MODIS Characterization Support Team, NASA Goddard Space Flight Center, available at: https:// www-misr.jpl.nasa.gov/getData/accessData/, last access: March 2015.

Moon, T., Wang, Y., Liu, Y., and Yu, B.: Evaluation of a MISR-Based High-Resolution Aerosol Retrieval Method Using AERONET DRAGON Campaign Data, IEEE Trans. Geosci. Remote Sens., 53, 4328-4339, doi:10.1109/TGRS.2015.2395722, 2015.

Neale, R. B., Rasch, P. J., Boville, B. A., Hack, J. J., McCaa, J. R., Williamson, D. L., Kiehl, J. T., Briegleb, B., Bitz, C., Lin, S. J., and Collins, W. D: Description of the NCAR community atmosphere model (CAM 5.0), NCAR Tech Note NCARTN-486 STR, available at: https://www.ccsm.ucar.edu/models/ccsm4.0/ cam/docs/description/cam4_desc.pdf (last access: 8 April 2016), 2010.

Olivier, J. G. J.: Applications of EDGAR Including a description of EDGAR 3.0: reference database with trend data for 1970-1995, Natl. Inst. Public Health Environ., Bilthoven, the Netherlands, 2001.

O’Neill, N. T., Dubovik, O., and Eck, T. F.: Modified Ångström exponent for the characterization of submicrometer aerosols, Appl. Opt., 40, 2368, doi:10.1364/AO.40.002368, 2001.

Pantillon, F., Knippertz, P., Marsham, J. H., Panitz, H.-J., and Bischoff-Gauss, I.: Modeling haboob dust storms in large-scale weather and climate models, J. Geophys. Res.-Atmos., 121, 2015JD024349, doi:10.1002/2015JD024349, 2016.

Park, R. J., Jacob, D. J., Chin, M., and Martin, R. V.: Sources of carbonaceous aerosols over the United States and implications for natural visibility, J. Geophys. Res.-Atmos., 108, 4355, doi:10.1029/2002JD003190, 2003.

Park, R. J., Jacob, D. J., Field, B. D., Yantosca, R. M., and Chin, M.: Natural and transboundary pollution influences on sulfate-nitrate-ammonium aerosols in the United States: Implications for policy, J. Geophys. Res.-Atmos., 109, doi:10.1029/2003JD004473, 2004.

Park, R. J., Jacob, D. J., Kumar, N., and Yantosca, R. M.: Regional visibility statistics in the United States: Natural and transboundary pollution influences, and implications for the Regional Haze Rule, Atmos. Environ., 40, 5405-5423, 2006.

Prospero, J. M.: African dust: Its large-scale transport over the Atlantic ocean and its impact on the Mediterranean region, in Regional Climate Variability and Its Impacts in the Mediterranean Area, 15-38, 2007.

Prospero, J. M., Ginoux, P., Torres, O., Nicholson, S. E., and Gill, T. E.: Environmental characterization of global sources of atmospheric soil dust identified with the Nimbus 7 Total Ozone Mapping Spectrometer (TOMS) absorbing aerosol product, Rev. Geophys., 40, 1002, doi:10.1029/2000rg000095, 2002.

Prospero, J. M., Collard, F.-X., Molinié, J., and Jeannot, A.: Characterizing the annual cycle of African dust transport to the Caribbean Basin and South America and its impact on the environment and air quality, Global Biogeochem. Cy., 28, GB004802, doi:10.1002/2013GB004802, 2014.
Pye, H. O. T. and Seinfeld, J. H.: A global perspective on aerosol from low-volatility organic compounds, Atmos. Chem. Phys., 10, 4377-4401, doi:10.5194/acp-10-4377-2010, 2010.

Pye, H. O. T., Chan, A. W. H., Barkley, M. P., and Seinfeld, J. H.: Global modeling of organic aerosol: the importance of reactive nitrogen $\left(\mathrm{NO}_{x}\right.$ and $\left.\mathrm{NO}_{3}\right)$, Atmos. Chem. Phys., 10, 1126111276, doi:10.5194/acp-10-11261-2010, 2010.

Quaas, J., Stevens, B., Stier, P., and Lohmann, U.: Interpreting the cloud cover - aerosol optical depth relationship found in satellite data using a general circulation model, Atmos. Chem. Phys., 10, 6129-6135, doi:10.5194/acp-10-6129-2010, 2010.

Rasch, P. J., Collins, W. D., and Eaton, B. E.: Understanding the Indian Ocean Experiment (INDOEX) aerosol distributions with an aerosol assimilation, J. Geophys. Res.-Atmos., 106, 7337-7355, 2001.

Reddington, C. L., Spracklen, D. V., Artaxo, P., Ridley, D. A., Rizzo, L. V., and Arana, A.: Analysis of particulate emissions from tropical biomass burning using a global aerosol model and long-term surface observations, Atmos. Chem. Phys., 16, 1108311106, doi:10.5194/acp-16-11083-2016, 2016.

Reid, J. S., Eck, T. F., Christopher, S. A., Hobbs, P. V., and Holben, B.: Use of the Angstrom exponent to estimate the variability of optical and physical properties of aging smoke particles in Brazil, J. Geophys. Res.-Atmos., 104, 27473-27489, doi:10.1029/1999JD900833, 1999.

Remer, L. A., Kaufman, Y. J., Tanré, D., Mattoo, S., Chu, D. A., Martins, J. V., Li, R.-R., Ichoku, C., Levy, R. C., Kleidman, R. G., Eck, T. F., Vermote, E., and Holben, B. N.: The MODIS Aerosol Algorithm, Products, and Validation, J. Atmos. Sci., 62, 947-973, doi:10.1175/JAS3385.1, 2005.

Remer, L. A., Mattoo, S., Levy, R. C., Heidinger, A., Pierce, R. B., and Chin, M.: Retrieving aerosol in a cloudy environment: aerosol product availability as a function of spatial resolution, Atmos. Meas. Tech., 5, 1823-1840, doi:10.5194/amt-5-1823-2012, 2012.

Ridley, D. A., Heald, C. L., and Ford, B.: North African dust export and deposition: A satellite and model perspective, J. Geophys. Res., 117, D02202, doi:10.1029/2011JD016794, 2012.

Ridley, D. A., Heald, C. L., Pierce, J. R., and Evans, M. J.: Toward resolution-independent dust emissions in global models: Impacts on the seasonal and spatial distribution of dust, Geophys. Res. Lett., 40, 2873-2877, doi:10.1002/grl.50409, 2013.

Ridley, D. A., Heald, C. L., and Prospero, J. M.: What controls the recent changes in African mineral dust aerosol across the Atlantic?, Atmos. Chem. Phys., 14, 5735-5747, doi:10.5194/acp14-5735-2014, 2014.

Rienecker, M. M., Suarez, M. J., Gelaro, R., Todling, R., Bacmeister, J., Liu, E., Bosilovich, M. G., Schubert, S. D., Takacs, L., Kim, G.-K., Bloom, S., Chen, J., Collins, D., Conaty, A., da Silva, A., Gu, W., Joiner, J., Koster, R. D., Lucchesi, R., Molod, A., Owens, T., Pawson, S., Pegion, P., Redder, C. R., Reichle, R., Robertson, F. R., Ruddick, A. G., Sienkiewicz, M., and Woollen, J.: MERRA: NASA's Modern-Era Retrospective Analysis for Research and Applications, J. Clim., 24, 3624-3648, doi:10.1175/JCLI-D-11-00015.1, 2011.

Sayer, A. M., Hsu, N. C., Bettenhausen, C., and Jeong, M.-J.: Validation and uncertainty estimates for MODIS Collection 6 "Deep Blue" aerosol data, J. Geophys. Res.-Atmos., 118, 7864-7872, doi:10.1002/jgrd.50600, 2013. 
Scanza, R. A., Mahowald, N., Ghan, S., Zender, C. S., Kok J. F., Liu, X., Zhang, Y., and Albani, S.: Modeling dust as component minerals in the Community Atmosphere Model: development of framework and impact on radiative forcing, Atmos. Chem. Phys., 15, 537-561, doi:10.5194/acp-15-537-2015, 2015.

Silverman, B.: Density Estimation for Statistics and Data Analysis, Chapman and Hall, 1986.

Sinyuk, A., Torres, O., and Dubovik, O.: Combined use of satellite and surface observations to infer the imaginary part of refractive index of Saharan dust, Geophys. Res. Lett., 30, 1081, doi:10.1029/2002GL016189, 2003.

Smirnov, A., Holben, B. N., Eck, T. F., Dubovik, O., and Slutsker, I.: Cloud-Screening and Quality Control Algorithms for the AERONET Database, Remote Sens. Environ., 73, 337-349, doi:10.1016/S0034-4257(00)00109-7, 2000.

Smirnov, A., Holben, B. N., Eck, T. F., Slutsker, I., Chatenet, B., and Pinker, R. T.: Diurnal variability of aerosol optical depth observed at AERONET (Aerosol Robotic Network) sites, Geophys. Res. Lett., 29, 2115, doi:10.1029/2002GL016305, 2002.

Smirnov, A., Holben, B. N., Slutsker, I., Giles, D. M., McClain, C. R., Eck, T. F., Sakerin, S. M., Macke, A., Croot, P., Zibordi, G., Quinn, P. K., Sciare, J., Kinne, S., Harvey, M., Smyth, T. J., Piketh, S., Zielinski, T., Proshutinsky, A., Goes, J. I., Nelson, N. B., Larouche, P., Radionov, V. F., Goloub, P., Krishna Moorthy, K., Matarrese, R., Robertson, E. J., and Jourdin, F.: Maritime Aerosol Network as a component of Aerosol Robotic Network, J. Geophys. Res.-Atmos., 114, D06204, doi:10.1029/2008JD011257, 2009.

Smirnov, A., Holben, B. N., Giles, D. M., Slutsker, I., O’Neill, N. T., Eck, T. F., Macke, A., Croot, P., Courcoux, Y., Sakerin, S. M., Smyth, T. J., Zielinski, T., Zibordi, G., Goes, J. I., Harvey, M. J., Quinn, P. K., Nelson, N. B., Radionov, V. F., Duarte, C. M., Losno, R., Sciare, J., Voss, K. J., Kinne, S., Nalli, N. R., Joseph, E., Krishna Moorthy, K., Covert, D. S., Gulev, S. K., Milinevsky, G., Larouche, P., Belanger, S., Horne, E., Chin, M., Remer, L. A., Kahn, R. A., Reid, J. S., Schulz, M., Heald, C. L., Zhang, J., Lapina, K., Kleidman, R. G., Griesfeller, J., Gaitley, B. J., Tan, Q., and Diehl, T. L.: Maritime aerosol network as a component of AERONET - first results and comparison with global aerosol models and satellite retrievals, Atmos. Meas. Tech., 4, 583-597, doi:10.5194/amt-4-583-2011, 2011.

Stauffer, D. R. and Seaman, N. L.: Use of Four-Dimensional Data Assimilation in a Limited-Area Mesoscale Model. Part I: Experiments with Synoptic-Scale Data, Mon. Weather Rev., 118, 1250-1277, doi:10.1175/15200493(1990)118<1250:UOFDDA>2.0.CO;2, 1990.

Streets, D. G., Bond, T. C., Carmichael, G. R., Fernandes, S. D., Fu, Q., He, D., Klimont, Z., Nelson, S. M., Tsai, N. Y., Wang, M. Q., Woo, J.-H., and Yarber, K. F.: An inventory of gaseous and primary aerosol emissions in Asia in the year 2000, J. Geophys. Res.-Atmos., 108, 8809, doi:10.1029/2002JD003093, 2003.

Streets, D. G., Zhang, Q., Wang, L. T., He, K. B., Hao, J. M., Wu, Y., Tang, Y. H., and Carmichael, G. R.: Revisiting China's $\mathrm{CO}$ emissions after the Transport and Chemical Evolution over the Pacific (TRACE-P) mission: Synthesis of inventories, atmospheric modeling, and observations, J. Geophys. Res.-Atmos., 111, JD007118, doi:10.1029/2006JD007118, 2006. van der Werf, G. R., Randerson, J. T., Giglio, L., Collatz, G. J., Kasibhatla, P. S., and Arellano Jr., A. F.: Interannual variability in global biomass burning emissions from 1997 to 2004, Atmos. Chem. Phys., 6, 3423-3441, doi:10.5194/acp-6-3423-2006, 2006.

van der Werf, G. R., Randerson, J. T., Giglio, L., Collatz, G. J., Mu, M., Kasibhatla, P. S., Morton, D. C., DeFries, R. S., Jin, Y., and van Leeuwen, T. T.: Global fire emissions and the contribution of deforestation, savanna, forest, agricultural, and peat fires (19972009), Atmos. Chem. Phys., 10, 11707-11735, doi:10.5194/acp10-11707-2010, 2010.

van Donkelaar, A., Martin, R. V., and Park, R. J.: Estimating ground-level $\mathrm{PM}_{2.5}$ using aerosol optical depth determined from satellite remote sensing, J. Geophys. Res.-Atmos., 111, D21201, doi:10.1029/2005JD006996, 2006.

Yu, Y., Notaro, M., Liu, Z., Wang, F., Alkolibi, F., Fadda, E., and Bakhrjy, F.: Climatic controls on the interannual to decadal variability in Saudi Arabian dust activity: Toward the development of a seasonal dust prediction model, J. Geophys. Res.-Atmos., 120, JD022611, doi:10.1002/2014JD022611, 2015.

Zaveri, R. A. and Peters, L. K.: A new lumped structure photochemical mechanism for large-scale applications, J. Geophys. Res. Atmos., 104, 30387-30415, doi:10.1029/1999JD900876, 1999.

Zaveri, R. A., Easter, R. C., Fast, J. D., and Peters, L. K.: Model for Simulating Aerosol Interactions and Chemistry (MOSAIC), J. Geophys. Res.-Atmos., 113, D13204, doi:10.1029/2007JD008782, 2008.

Zender, C. S.: Mineral Dust Entrainment and Deposition (DEAD) model: Description and 1990s dust climatology, J. Geophys. Res., 108, doi:10.1029/2002JD002775, 2003.

Zhang, L., Kok, J. F., Henze, D. K., Li, Q., and Zhao, C.: Improving simulations of fine dust surface concentrations over the western United States by optimizing the particle size distribution, Geophys. Res. Lett., 40, 3270-3275, doi:10.1002/grl.50591, 2013.

Zhang, Q., Streets, D. G., Carmichael, G. R., He, K. B., Huo, H., Kannari, A., Klimont, Z., Park, I. S., Reddy, S., Fu, J. S., Chen, D., Duan, L., Lei, Y., Wang, L. T., and Yao, Z. L.: Asian emissions in 2006 for the NASA INTEX-B mission, Atmos. Chem. Phys., 9, 5131-5153, doi:10.5194/acp-9-5131-2009, 2009.

Zhao, C., Liu, X., Leung, L. R., Johnson, B., McFarlane, S. A., Gustafson Jr., W. I., Fast, J. D., and Easter, R.: The spatial distribution of mineral dust and its shortwave radiative forcing over North Africa: modeling sensitivities to dust emissions and aerosol size treatments, Atmos. Chem. Phys., 10, 8821-8838, doi:10.5194/acp-10-8821-2010, 2010.

Zhao, C., Ruby Leung, L., Easter, R., Hand, J., and Avise, J.: Characterization of speciated aerosol direct radiative forcing over California, J. Geophys. Res.-Atmos., 118, 2372-2388, doi:10.1029/2012JD018364, 2013.

Zhao, C. Z. C., Liu, X., Leung, L. R., and Hagos, S.: Radiative impact of mineral dust on monsoon precipitation variability over West Africa, Atmos. Chem. Phys., 11, 1879-1893, doi:10.5194/acp-11-1879-2011, 2011. 